Taxonomy and systematics

\title{
The caridean shrimps (Crustacea: Decapoda: Caridea: Alpheoidea, Palaemonoidea, and Processoidea) from Bahía Chamela, Mexico
}

\author{
Camarones carideos (Crustacea: Decapoda: Caridea: Alpheoidea, Palaemonoidea y Processoidea) \\ de la bahía Chamela, México
}

\author{
Manuel Ayón-Parente ${ }^{\mathrm{a}, *}$, Margarita Hermoso-Salazar ${ }^{\mathrm{b}}$, Michel E. Hendrickx ${ }^{\mathrm{c}}$, \\ Cristian Moisés Galván-Villa a , Eduardo Ríos-Jara ${ }^{\mathrm{a}}$, Dafne Bastida-Izaguirre ${ }^{\mathrm{a}}$ \\ ${ }^{a}$ Laboratorio de Ecosistemas Marinos y Acuicultura, Departamento de Ecología, Centro Universitario de Ciencias Biológicas y Agropecuarias, \\ Universidad de Guadalajara, Carretera a Nogales km. 15.5, Las Agujas Nextipac, 45110 Zapopan, Jalisco, Mexico

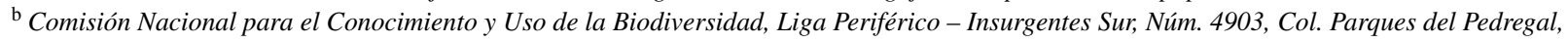 \\ Delegación Tlalpan, 14010, México D.F., Mexico \\ ${ }^{c}$ Laboratorio de Invertebrados Bentónicos, Unidad Académica Mazatlán, Instituto de Ciencias del Mar y Limnología, Universidad Nacional Autónoma de México, \\ P.O. Box 811, 82000 Mazatlán, Sinaloa, Mexico
}

Received 11 May 2015; accepted 11 November 2015

Available online 25 May 2016

\begin{abstract}
During a faunistic survey of the islands and islets of Bahía Chamela, Jalisco, Mexico, 40 species of caridean shrimps belonging to 5 families were collected; the Alpheidae with 3 genera and 20 species was the best represented, followed by the Palaemonidae with 10 genera and 12 species. Other families found were: Hippolytidae ( 3 genera, 5 species), Gnathophyllidae ( 1 genus, 1 species), and Processidae ( 1 genus, 2 species). Compared with the rest of the Mexican Pacific, the number of species found represents $44 \%$ of the genera and $45 \%$ of the benthic species of caridean shrimps reported to date. Ninety percent of the species collected correspond to new records for Bahía Chamela. Two species, Neopontonides henrivronprahli from Costa Rica and Colombia, and Thor cocoensis from Costa Rica and the Galápagos Islands, are recorded for the first time since their original description, extending their distribution range by ca 16 and 14 degrees of latitude to the north, respectively.

All Rights Reserved (c) 2016 Universidad Nacional Autónoma de México, Instituto de Biología. This is an open access item distributed under the Creative Commons CC License BY-NC-ND 4.0.

Keywords: New records; Jalisco; Tropical Mexican Pacific; Biodiversity

\section{Resumen}

Como resultado de un estudio faunístico realizado en la bahía Chamela, Jalisco, se recolectó un total de 40 especies de carideos pertenecientes a 5 familias; los Alpheidae con 3 géneros y 20 especies fueron los mejor representados, seguidos por los Palaemonidae con 10 géneros y 12 especies. Otras familias fueron: Hippolytidae ( 3 géneros y 5 especies), Gnathophyllidae (1 género, 1 especie) y Processidae (1 género, 2 especies). Comparado con el resto del Pacífico mexicano, el número de especies encontradas representan el $44 \%$ de los géneros y el $45 \%$ de las especies de camarones carideos bentónicos registrados hasta la fecha. El 90\% de las especies recolectadas corresponde a nuevos registros para la bahía Chamela. Dos especies, Neopontonides henrivronprahli de Costa Rica y Colombia, y Thor cocoensis de Costa Rica y las islas Galápagos, se registran por primera vez desde su descripción original, extendiendo su distribución aproximadamente 16 y 14 grados de latitud al norte, respectivamente. Derechos Reservados (C) 2016 Universidad Nacional Autónoma de México, Instituto de Biología. Este es un artículo de acceso abierto distribuido bajo los términos de la Licencia Creative Commons CC BY-NC-ND 4.0.
\end{abstract}

Palabras clave: Registros nuevos; Jalisco; Pacífico tropical mexicano; Biodiversidad

\footnotetext{
* Corresponding author.

E-mail address: manuel_aparente@hotmail.com (M. Ayón-Parente).

Peer Review under the responsibility of Universidad Nacional Autónoma de México.
} 


\section{Introduction}

Among the decapod crustaceans, the infraorder Caridea is one of the best represented around the world with just over 3400 species (Ahyong et al., 2011). In the tropical eastern Pacific, this group of shrimps is also one of the most diverse with approximately 206 benthic species. The Alpheidae (79 species) and Palaemonidae (60) contain the largest number (Anker \& Pachelle, 2013; Hermoso-Salazar \& Hendrickx, 2005; Wicksten \& Hendrickx, 2003). Most records for these groups of species, however, are from intertidal habitats. The sandy, muddy and rocky subtidal habitats have been poorly studied, although there is a sizable series of samples that have been collected by trawls or small dredges in soft or mixed bottoms in shallow bays (e.g., Álvarez-del Castillo, Hendrickx, \& Rodríguez, 1992).

Very little systematic sampling has been done by SCUBA diving except in some selected areas of the Baja California Peninsula (Hernández, Balart, \& Reyes-Bonilla, 2008, 2009; Hernández, Reyes-Bonilla, \& Balart, 2010). Recent studies of benthic caridean shrimps along the Pacific coast of Mexico have allowed the description of new species (e.g., AyónParente \& Salgado-Barragán, 2013; Ayón-Parente, Hendrickx, \& Galván-Villa, 2015; Hermoso-Salazar \& Álvarez, 2005; Hermoso-Salazar \& Hendrickx, 2005; Salgado-Barragán, AyónParente, \& Hendrickx, 2014), the revision of the taxonomic status of others (e.g., Anker \& Pachelle, 2013; Anker, Hurt, Jara, \& Knowlton, 2008; Anker, Hurt, \& Knowlton, 2008b), the obtention of new information dealing with ecological aspects (e.g., Hermoso-Salazar \& Hendrickx, 2005; Martínez-Guerrero \& Hendrickx, 2011), and new records and range extensions (e.g., Álvarez, Camacho, \& Villalobos, 1996; Ayón-Parente, Hendrickx, \& Ríos-Jara, 2012; Hendrickx \& Wicksten, 2011; Hendrickx, 2008; Hermoso-Salazar \& Hernández-Alcántara, 2001; Hermoso-Salazar \& Suárez-González, 2001). This suggests that the information on shallow water caridean shrimps of the Mexican Pacific is far from being complete.

The general polygon Sanctuary of Bahía Chamela covers 1981 ha and includes a series of islands and islets, each with very specific environmental conditions, thus potentially offering niches for a great marine biodiversity (Miranda, Ambriz, Valencia, Sánchez, \& Szekely, 2011). Although this sanctuary has received protected area status since 2002, the knowledge on the invertebrate fauna inhabiting this large ecosystem, particularly the decapod crustaceans, is scarce (Bastida-Izaguirre, Ayón-Parente, Salgado-Barragán, Galván-Villa, \& Ríos-Jara, 2013). In Mexico, as in other countries, one of the main priorities in protected areas is to guarantee a sustainable management and the conservation of biodiversity. Consequently, an intensive survey of the decapod fauna of this protected area was recently organized (2007-2013). This paper presents the records of the caridean shrimps collected during this survey as a contribution to the knowledge of the biodiversity of this important region in the central Mexican Pacific.

\section{Material and methods}

The material reported in this paper was collected between July 2007 and June 2013 in Bahía Chamela, Jalisco, Mexico (Fig. 1). The specimens were obtained by hand, snorkeling, scuba diving, and with a $26 \mathrm{~cm} \times 44 \mathrm{~cm}$ biological dredge. Most specimens were sexed and the carapace length measured in $\mathrm{mm}$ to the nearest $0.1 \mathrm{~mm}$ from the orbit to the posterior margin of the carapace. The specimens were deposited in the Reference Collection of the Laboratory of Marine Ecosystems and Aquaculture (LEMA-CCR), University Center for Biological and Agricultural Sciences (CUCBA-UDG), in Zapopan, Jalisco. Species distribution reported herein only refers to the Mexican Pacific. Synonymy is provided only for species of Alpheus that

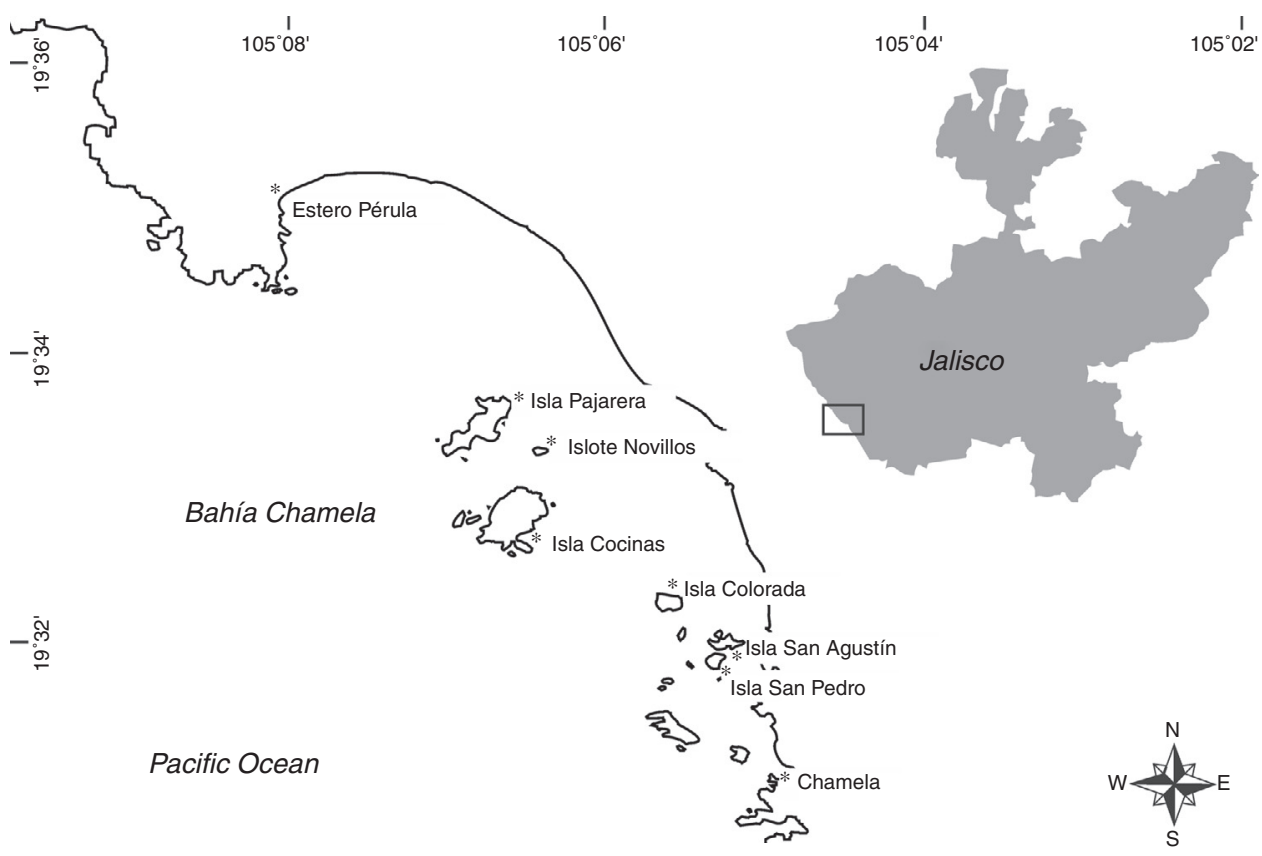

Figure 1. Location of sampling sites in Bahía Chamela. 
have been reviewed after the monographic revision by Kim and Abele (1988). Names of localities are in Spanish to avoid confusion. Abbreviations used: CL, carapace length; NS, not sexed; NM, not measured.

\section{Results}

Superfamily Alpheoidea Rafinesque, 1815

Family Alpheidae Rafinesque, 1815

Alpheus arenensis (Chace, 1937)

Crangon arenensis Chace, 1937: 119, Fig. 4.

Alpheus arenensis. Crosnier \& Forest, 1966: 236. Rodríguezde la Cruz, 1977: 29; 1987: 43. Carvacho \& Ríos, 1982: 282. Anker et al., 2008b: 59, Figs. 3E, 4B.

Alpheus websteri (not sensu Kingsley, 1880). Wicksten, 1983: 42 (partim); 1993: 151. Wicksten \& Hendrickx, 1985: 572; 1992: 5 (partim); 2003: 65 (partim). Kim \& Abele, 1988: 28, Fig. 11. Villalobos-Hiriart et al., 1989: 17. Hendrickx, 1993b: 6; 1995: 432. Salazar-Rosas, 1995: 59, Pl. 17. Camacho, 1996: 64. Hermoso-Salazar, 1999: 59, Pl. 19, Fig. 9. Vargas \& Cortés, 1999: 902. Villalobos-Hiriart, 2000: 66, Fig. 33. McClure, 2005: 157, Fig. 24 (reproduced from Kim and Abele (1988)).

Alpheus ridleyi. Crosnier \& Forest, 1966: 230, 232, 236. Chace, 1972: 69. Coelho \& Ramos, 1972: 140. Fausto-Filho, 1974: 5. Rodríguez, 1980: 149.

Material examined. One male (CL $3.3 \mathrm{~mm}$ ), Novillos, $28 \mathrm{Nov}$ 2011, scuba diving, $5 \mathrm{~m}$, coral, LEMA-CCR111. 1 female (CL $2.0 \mathrm{~mm}$ ), Isla Cocinas, 27 Jun 2013, snorkel, 3 m, coral, LEMACCR451.

Previous records in Mexico. Gulf of California, Baja California Sur: Punta Chivato (Rodríguez-de la Cruz, 1987), Banco Arena (Chace, 1937), Punta Arenas (Carvacho \& Ríos, 1982), Isla Espíritu Santo, Isla Cerralvo (Villalobos-Hiriart et al., 1989), southern Gulf of California (Wicksten, 1983). Sonora: Morro Colorado (Wicksten \& Hendrickx, 1985). Sinaloa: Southern Sinaloa (Hendrickx, 1993b). Nayarit: Isla Isabel (Camacho, 1996). Colima: Bahía Santiago, Manzanillo, Isla Socorro (Hermoso-Salazar, 1999).

Remarks. In the short monographic work on the shallow water caridean shrimps of the Gulf of California, Wicksten (1983) considered Alpheus arenensis, Alpheus fagei Crossnier and Forest, 1965 and $A$. ridleyi Pocock, 1890 to be junior synonyms of A. websteri. The argument was that morphological differences found in the specimens revised from the eastern Pacific, the Caribbean, and the western Atlantic, were not sufficient to consider these as different species. Anker et al. (2008a) carried out a comparative study of the $A$. websteri species complex using fresh material collected in the Caribbean, the western Atlantic and the eastern Pacific (for more detail see Anker et al. (2008a)). The results of the morphological analysis between A. arenensis (from Panama Pacific) and A. websteri (from the western Atlantic and the Caribbean) show only a slight morphological difference (presence of a small distal tooth on the merus of the major cheliped in A. websteri, which is absent in A. arenensis); differences in the color pattern were also minor, but the molecular data indicated that both species represent transisthmian sister species.

\section{Alpheus cylindricus Kingsley, 1878}

Alpheus cylindricus Kingsley, 1878a: 196; 1878b: 58. Lockington, 1878: 478; 1883: 120. Rodríguez-de la Cruz, 1977: 28. Carvacho \& Ríos, 1982: 282. Wicksten, 1983: 43 (partim). Kim \& Abele, 1988: 47, Fig. 19. Villalobos-Hiriart et al., 1989: 18. Flores-Hernández, 1991: 96. Álvarez-del Castillo et al., 1992: 5. Wicksten \& Hendrickx, 1992: 4 (partim). Hendrickx, 1992: 8; 1993a: 306; 1993b: 6; 1995: 432. Lemaitre and AlvarezLeón,1992: 42. Knowlton et al., 1993: 1630 (partim). Camacho, 1996: 67. Villalobos, 2000: 47, Fig. 23. Williams, Knowlton, Weigt, \& Jara, 2001: 377 (partim). Wicksten \& Hendrickx, 2003: 63 (partim). Anker et al., 2008a: Figs. 1; 3A, D; 4A-D, I.

Crangon cylindricus. Chace, 1937: 121. Schmitt, 1939: 24.

Alpheus cylindrius (misspelled). Vargas \& Cortés, 1999: 899.

Not Alpheus cylindricus. Crosnier and Forest,1966: 257, Fig. 16. Coelho \& Ramos, 1972: 149. Chace, 1972: 65. Pequegnat \& Ray, 1974: 246, Fig. 49d. Ray, 1974: 92, Figs. 72-78. Christoffersen, 1979: 310; 1980: 50. Coelho \& Ramos, 1980: 135. Abele \& Kim, 1986: 196, 206-207, Fig. a-c. Sterrer, 1986: 326, text. pl. 105, pl. 9, Fig. 7. Rodríguez, 1986: 138, Fig. 33. Martínez-Iglesias, Gómez, Carvacho, \& Ríos, 1993: 11. Knowlton et al., 1993: 1630 (partim). Martínez-Iglesias, Carvacho, \& Ríos, 1996: 33; 1997: 404, Fig. 9. Williams et al., 2001: 377 (partim). McClure, 2005: 138, Fig. 11 (reproduced from Kim \& Abele, 1988). Coelho, de Almeida, de Souza-Filho, Bezerra, \& Giraldes, 2006: 51 (=A. vanderbilti Boone, 1930).

Material examined. One female (CL $3.6 \mathrm{~mm}$ ), Isla Cocinas, 5 Mar 2013, snorkel, 2-3 m, polychaete-tube reef, LEMACCR101.

Previous records in Mexico. Gulf of California, Baja California Sur: Banco Arena (Chace, 1937), Isla Espíritu Santo (Kim \& Abele, 1988; Wicksten, 1983), Isla Cerralvo (VillalobosHiriart et al., 1989). Sinaloa: Southern Sinaloa (Hendrickx, 1993b). Nayarit: Punta de Mita (Camacho, 1996; HermosoSalazar, 1999), Isla Isabel (Camacho, 1996; Kim \& Abele, 1988; Wicksten, 1983). Jalisco: Barra de Navidad (Álvarez-del Castillo et al., 1992).

Remarks. Previously to the revision of Alpheus cylindricus s.l. by Anker et al. (2008a), this species was considered widely distributed in the tropical eastern Pacific, western and eastern Atlantic. The detailed examination of specimens collected throughout its distribution range, however, indicated that 2 different species had been treated under the same name (see Anker et al., 2008b). As a result, Alpheus vanderbilti Boone, 1930 was resurrected from the synonymy of $A$. cylindricus. The first species is now known to occur in the tropical western Atlantic and in the tropical eastern Atlantic, while the second one is restricted to the tropical eastern Pacific, from the Gulf of California to the Islas Galápagos (see Anker et al. (2008a) for more information).

Alpheus galapagensis Sivertsen, 1933

Alpheus strenuus var. galapagensis Sivertsen, 1933: 3, pl. 1, Figs. 1-5. 
Alpheus strenuus galapagensis. Banner \& Banner, 1966: 184. Banner \& Banner, 1982: 228.

Alpheus canalis Kim \& Abele, 1988: 72, Fig. 20.

Alpheus galapagensis. Kim \& Abele, 1988: 102, Fig. 43. McClure \& Wicksten, 2000: 968, Fig. 3. Anker, Hurt, \& Knowlton, 2007: 47, Figs. 2, 5B, 6B, 7D-F, 8B.

Material examined. One ovigerous female (CL $4.5 \mathrm{~mm}$ ), Isla San Pedro, 06 Mar, 2013, by hand, intertidal, under rocks, LEMA-CCR86.

Previous records in Mexico. Gulf of California, Baja California: Isla Las Animas (Villalobos-Hiriart et al., 1989). Baja California Sur: Bahía Concepción (Ríos, 1992), Isla San Marcos, Isla Coronado, Isla Carmen, Isla San José (Villalobos-Hiriart et al., 1989), Isla San Francisco (Kim \& Abele, 1988; McClure \& Wicksten, 2000), Isla Espíritu Santo, Isla Cerralvo (VillalobosHiriart et al., 1989). Sonora: Los Algodones, Ensenada de San Francisco (Kim \& Abele, 1988), Guaymas (McClure \& Wicksten, 2000), Isla Tiburón (Villalobos-Hiriart et al., 1989). Sinaloa: Punta Chile (McClure \& Wicksten, 2000), Southern Sinaloa (Hendrickx, 1993b). Nayarit: Estero San Cristóbal, Punta El Caballo Santa Cruz (Camacho, 1996), Punta de Mita (Camacho, 1996; Hermoso-Salazar, 1999), Isla Isabel (Camacho, 1996; Kim \& Abele, 1988), Isla María Madre (Hermoso-Salazar, 1999; Hernández-Aguilera \& MartínezGuzmán, 1992), Isla Jaltemba (Kim \& Abele, 1988). Colima: Bahía Santiago (Hermoso-Salazar, 1999). Oaxaca: Bahía La Entrega (Hermoso-Salazar, 1999), Tangola-Tangola (Kim \& Abele, 1988).

Remarks. McClure \& Wicksten (2000) and later Anker et al. (2007) reviewed material of A. galapagensis and A. canalis and did not find morphological characteristics that could distinguish these 2 species. As a result they concluded that A. canalis is a junior synonym of $A$. galapagensis.

\section{Alpheus lottini Guérin-Méneville, 1838}

Material examined. One male (CL $3.0 \mathrm{~mm}$ ), Novillos, 28 Nov 2011, scuba diving, 4-5 m, Pocillopora coral, LEMACCR112. 1 male (CL $4.6 \mathrm{~mm}$ ), 1 ovigerous female (CL $5.3 \mathrm{~mm}$ ), Novillos, 5 Mar 2013, scuba diving, 4 m, Pocillopora coral, LEMA-CCR113. 1 male (CL $5.0 \mathrm{~mm}$ ), 1 ovigerous female (CL $6.1 \mathrm{~mm}$ ), Chamela, 6 Mar 2013, gill net, Pocillopora coral, LEMA-CCR114. 1 male (CL $7.7 \mathrm{~mm}$ ), 1 ovigerous female (CL $10.0 \mathrm{~mm}$ ), Isla Pajarera, 27 Jun 2013, snorkel, 3-5 m, Pocillopora coral, LEMA-CCR115. 1 male (CL $5.8 \mathrm{~mm}$ ), Isla Pajarera, 26 Jun 2013, snorkel, 7 m, Pocillopora coral, LEMA-CCR133.

Previous records in Mexico. Gulf of California, Baja California Sur: Southern Gulf of California (Wicksten, 1983), Banco Arena (Chace, 1937), Cabo San Lucas, Bahía La Paz (Hernández et al., 2008, 2010; Hernández, Ramírez-Ortiz, \& Reyes-Bonilla, 2013), Bahía Loreto (Hernández et al., 2010, 2013), Isla Coronado (Hernández et al., 2009), Isla San José, Isla Espíritu Santo, Isla Cerralvo (Villalobos-Hiriart et al., 1989). Nayarit: Bahía Chacala (Rodríguez-Almaraz, Leija-Tristán, \& Mendoza, 2000), Punta de Mita (Camacho, 1996; Hermoso-Salazar, 1999), Rincón de Guayabitos (Hendrickx, 1994), Isla María Madre (Hermoso-Salazar, 1999), Islas Marías (Hernández et al., 2013), Isla Isabel (Camacho, 1996; Kim \& Abele, 1988; López-Uriarte
\& Ríos-Jara, 2004), Islas Marietas (Hernández et al., 2013). Jalisco: Bahía Chamela, Bahía de Tenacatita (López-Uriarte \& Ríos-Jara, 2004). Colima: Bahía Santiago (Hermoso-Salazar, 1999), Isla Socorro (Hermoso-Salazar, 1999; Kim \& Abele, 1988; Wicksten, 1983), Isla Clarión (Kim \& Abele, 1988). Guerrero: Punta Ixtapa, Morros del Potosí (Hernández et al., 2013). Oaxaca: Bahía Santa Cruz, Bahía La Entrega (Hermoso-Salazar, 1999), Estacahuite (Hernández et al., 2013), Bahía Santiago (Hermoso-Salazar, 1999).

Remarks. All specimens were collected in Pocillopora coral, confirming that the species is a commensal obligate of Pocillopora spp. as mentioned by Kim and Abele (1988).

Alpheus paracrinitus Miers, 1881

Material examined. One male (CL $3.3 \mathrm{~mm}$ ), 1 female (CL $2.8 \mathrm{~mm}$ ), 1 ovigerous female (CL $3.8 \mathrm{~mm}$ ), Novillos, $5 \mathrm{Mar}$ 2013, scuba diving, $4 \mathrm{~m}$, Pocillopora coral, LEMA-CCR134. 1 male (CL 2.0 mm), 1 NS, NM, Isla Cocinas, 5 Mar 2013, snorkel, 2-3 m, polychaete-tube reef, LEMA-CCR157.

Previous records in Mexico. Gulf of California, Baja California Sur: Bahía Agua Verde (Hendrickx, 2005; Wicksten, 1983), Isla Espíritu Santo, Isla San Francisco (Kim \& Abele, 1988), Isla Cerralvo (Villalobos-Hiriart et al., 1989). Sonora: Isla San Pedro Nolasco (Hendrickx, 2005; Wicksten, 1983). Nayarit: Punta de Mita, Isla Isabel (Camacho, 1996). Colima: Isla Clarión (Kim \& Abele, 1988; Wicksten, 1983). Guerrero: Bahía Santa Lucia, Acapulco (Wicksten, 1983).

Remarks. Wicksten and Hendrickx (2003) noted that Alpheus fasciatus Lockington, 1878 might be a junior synomym of $A$. paracrinatus. A detailed review of fresh material of these species is necessary, as well as a comparative molecular based analysis to clarify their taxonomic status.

Alpheus rostratus Kim \& Abele, 1988

Material examined. Two females (CL 2.7-2.9 mm), Isla Pajarera, 7 Mar 2013, snorkel, 2 m, rocks, LEMA-CCR105.

Previous records in Mexico. Gulf of California, Baja California Sur: Bahía Concepción (Ríos, 1992), Isla Espíritu Santo (Kim \& Abele, 1988). Nayarit: Isla Isabel (Camacho, 1996; Kim \& Abele, 1988).

Remarks. The material from Bahía Chamela is the fourth record for Mexico since the species was described and represents a new southernmost distribution limit for the Mexican Pacific.

\section{Alpheus sulcatus Kingsley, 1878b}

Material examined. Three males (CL 3.5-5.0 mm), Isla San Agustín, 25 Nov 2011, scuba diving, 9 m, rocks, LEMA-CCR99.

Previous records in Mexico. West coast of Baja California Sur: Bahía Magdalena (Wicksten \& Méndez, 1983). Gulf of California, Baja California: Isla Salsipuedes, Isla Las Animas (Villalobos-Hiriart et al., 1989). Gulf of California, Baja California Sur: Los Frailes (Wicksten \& Méndez, 1983), Isla San Marcos (Villalobos-Hiriart et al., 1989), Isla Coronado (Hernández et al., 2009; Villalobos-Hiriart et al., 1989), Isla Carmen (Hernández et al., 2009), Isla San José (Villalobos-Hiriart et al., 1989), Isla Espíritu Santo (Kim \& Abele, 1988), Isla Cerralvo (Villalobos-Hiriart et al., 1989). Golfo de California 
(Wicksten, 1983). Sonora: Isla San Esteban (Villalobos-Hiriart et al., 1989). Sinaloa: Isla Pájaros (Arzola-González, FloresCampaña, \& Vázquez-Cervantes, 2010; Hendrickx, 1994; Hendrickx \& Wicksten, 1987), Isla Lobos (Arzola-González et al., 2010), southern Sinaloa (Hendrickx, 1993b). Nayarit: Punta de Mita (Camacho, 1996; Hermoso-Salazar, 1999), Isla Isabel (Camacho, 1996), Isla María Madre (Hermoso-Salazar, 1999; Hernández-Aguilera \& Martínez-Guzmán, 1992), Isla Jaltemba (Kim \& Abele, 1988). West coast of Mexico (Wicksten \& Méndez, 1983).

Remarks. The material collected in Bahía Chamela represents the southernmost record for this species along the coast of the Mexican Pacific.

\section{Alpheus utriensis Ramos \& Von Prahl, 1989}

Alpheus utriensis Ramos \& Von Prahl, 1989: 477, Figs. 1 and 2. Anker et al., 2008a: 552, Figs. 4, 5, 7C and D.

Alpheus cristulifrons (not sensu Rathbun, 1900). Wicksten, 1983: 44. Kim \& Abele, 1988: 44, Fig. 18. Villalobos-Hiriart et al., 1989: 19. Flores-Hernández, 1991: 99. Wicksten \& Hendrickx, 1992: 4; 2003: 63; Hendrickx, 1992: 8; 1993a: 306; 1995: 432. Camacho, 1996: 72. Villalobos-Hiriart, 2000: 45, Fig. 22. McClure, 2005: 136 (partim), Fig. 10. Hendrickx \& Hermoso-Salazar, 2005.

Material examined. One female (CL $3.2 \mathrm{~mm}$ ), Novillos, 5 Mar 2013, scuba diving, 4 m, Pocillopora coral, LEMA-CCR80. 1 ovigerous female (CL $4.2 \mathrm{~mm}$ ), 1 NS (CL $3.9 \mathrm{~mm}$ ), Novillos, 28 Nov 2011, LEMA-CCR81. 1 female (CL 1.9 mm), Isla Cocinas, 5 Mar 2013, snorkel, 3 m, dead coral, LEMA-CCR89. 1 ovigerous female (CL 2.4 mm), Isla Pajarera, 26 Jun 2013, scuba diving, $7 \mathrm{~m}$, dead coral, LEMA-CCR130.

Previous records in Mexico. Gulf of California, Baja California: off Cabo San Miguel (Hendrickx \& Hermoso-Salazar, 2005; Hendrickx \& Wicksten, 2011). Baja California Sur: Puerto Escondido (Wicksten, 1983), Isla Espíritu Santo (VillalobosHiriart et al., 1989). Nayarit: Isla Isabel (Kim \& Abele, 1988; Wicksten, 1983), off Islas Tres Marías (Hendrickx \& HermosoSalazar, 2005). Guerrero: Bahía Santa Lucia (Wicksten, 1983).

Remarks. Using different tools (molecular data, morphology, and color patterns) and after a detailed revision of material belonging to Alpheus cristulifrons Rathbun, 1900 (from eastern and western Atlantic) and A. utriensis Ramos \& Von Prahl, 1989 (from eastern Pacific), Anker et al. (2008a) concluded that both species were valid. The material from Bahía Chamela represents the fifth record of the species from the Mexican Pacific and the second south of the Gulf of California.

Alpheus wonkimi Anker \& Pachelle, 2013

Alpheus malleator. Dana, 1852: 557 (records from the eastern Pacific; fide Kim \& Abele, 1988). Crosnier \& Forest, 1966: 240, Fig. 10. Chace, 1972: 68. Abele, 1975: 72. Wicksten, 1983: 43. Banner \& Banner, 1984: 42. Kim \& Abele, 1988: 31, Fig. 12.

Crangon malleator. Rathbun, 1910: 607. Schmitt, 1939: 24.

Alpheus wonkimi Anker \& Pachelle, 2013: 422, Figs. 7-10, 11I, J.

Material examined. One male (CL $1.8 \mathrm{~mm}$ ), Novillos, $5 \mathrm{Mar}$ 2013, scuba diving, 4 m, coral, LEMA-CCR103. 4 females (CL
2.9-9.4 mm), 1 ovigerous female (CL $9.5 \mathrm{~mm}$ ), Isla Cocinas, 28 Nov 2011, snorkel, 2 m, polychaete-tube reef, LEMA-CCR104.

Previous records in Mexico. Gulf of California, Baja California Sur: Cabo Pulmo (Steinbeck \& Ricketts, 1941). Sinaloa: Punta Piaxtla (Hendrickx \& Hermoso-Salazar, 2005; Hendrickx \& Wicksten, 1987), south of Sinaloa (Hendrickx, 1993b). Nayarit: Punta de Mita (Camacho, 1996; Hendrickx \& HermosoSalazar, 2005; Hermoso-Salazar, 1999), Isla Isabel (Camacho, 1996), Isla Tres Marías (Wicksten, 1983). Jalisco: Bahía Banderas (Hendrickx \& Hermoso-Salazar, 2005), Barra de Navidad (Kim \& Abele, 1988), Bahía Chamela (López-Uriarte \& RíosJara, 2004), Bahía Tenacatita (López-Uriarte \& Ríos-Jara, 2004; Wicksten, 1983). Colima: Bahía Santiago (Hermoso-Salazar, 1999). Guerrero: Bahía Santa María, Acapulco (Wicksten, 1983). Oaxaca: Bahía La Entrega (Hermoso-Salazar, 1999).

Remarks. Anker and Pachelle (2013) conducted a reexamination of Alpheus malleator based on material from the eastern Pacific and the Atlantic in order to clarify its taxonomic status throughout its distribution range. They concluded that the material from the eastern Pacific represented a different species which they named A. wonkimi Anker \& Pachelle, 2013. The Atlantic A. malleator represents a single, widespread, morphologically variable, amphi-Atlantic species.

\section{Pomagnathus corallinus Chace, 1937}

Material examined. One female (CL $2.5 \mathrm{~mm}$ ), Isla San Agustín, 25 Nov 2011, scuba diving, 9 m, rocks, LEMA-CCR88.

Previous records in Mexico. Gulf of California, Baja California Sur: Bahía Concepción (Rodríguez-de la Cruz, 1987), Banco Arena (Chace, 1937), Isla Danzante (Hernández et al., 2009), Isla San José (Villalobos-Hiriart et al., 1989), Isla Espíritu Santo (Wicksten, 1983; Villalobos-Hiriart et al., 1989), Isla Cerralvo. Nayarit: Punta de Mita (Camacho, 1996; Hermoso-Salazar, 1999), Isla Isabel (Camacho, 1996; Wicksten, 1983). Colima: Isla Clarión (Wicksten, 1983), Isla Socorro (Hermoso-Salazar, 1999). Michoacán: Caleta de Campos (Hermoso-Salazar \& Hernández-Alcántara, 2001).

Remarks. According to Abele (1976) this species is considered an obligatory symbiont of corals; however, our specimen was collected in interstices of rocks close to a coral reef.

\section{Synalpheus bannerorum Abele, 1975}

Material examined. One female (CL $1.5 \mathrm{~mm}$ ), Isla Pajarera, 26 Jun 2013, scuba diving, 7 m, dead coral, LEMA-CCR129.

Previous records in Mexico. Gulf of California, Baja California Sur: Bahía La Paz (Hermoso-Salazar, 2009; Hermoso-Salazar \& Suárez-González, 2001). Nayarit: Estero San Cristobal, Punta de Mita, Bahía Chacala (Álvarez et al., 1996; Camacho, 1996; Hermoso-Salazar, 2009).

Remarks. Synalpheus bannerorum is easily distinguished from other species of the genus occurring in the eastern Pacific by the presence of movable spines on the merus of the third and fourth pairs of pereiopods.

\section{Synalpheus brevispinis Coutière, 1909}

Material examined. Four males (CL 3.0-3.3 mm), 6 females (CL 2.3-3.9 mm), 2 ovigerous females (CL $3.0-3.5 \mathrm{~mm}$ ), 
Novillos, 5 Mar 2013, LEMA-CCR82. 2 males (CL 2.8-4.0 mm), 1 female (CL $2.3 \mathrm{~mm}$ ), 3 ovigerous females (CL 3.3-4.8 mm), Isla Cocinas, 28 Nov 2011, snorkel, $2 \mathrm{~m}$, rocks, LEMA-CCR100. 1 female (CL $2.7 \mathrm{~mm}$ ), Isla Cocinas, $28 \mathrm{Nov}$ 2011, snorkel, $3 \mathrm{~m}$, polychaete-tube reef, LEMA-CCR127. 3 females (CL 2.5-2.8 mm), Isla Cocinas, 5 Mar 2013, snorkel, $2 \mathrm{~m}$, polychaete-tube reef, LEMA-CCR154.

Previous records in Mexico. Baja California (Coutière, 1909). Baja California Sur: Los Islotes, Calerita and Punta Chileno, Cabo San Lucas (Hermoso-Salazar, 2009; HermosoSalazar, Wicksten, \& Morrone, 2005). Sonora: Puerto Peñasco (Hermoso-Salazar et al., 2005). Nayarit: Bahía Chacala, Playa Careceros, Punta de Mita (Camacho, 1996; Hermoso-Salazar, 1999, 2009, as S. biunguiculatus), Isla Isabel (Camacho, 1996; Hermoso-Salazar, 2009, as S. biunguiculatus), Isla María Madre (Hermoso-Salazar, 1999, as S. biunguiculatus). Colima: Bahía Santiago, Manzanillo, Isla Socorro (Hermoso-Salazar, 1999, as S. biunguiculatus), Isla Clarión (Hermoso-Salazar, 1999, 2009, as S. biunguiculatus). Oaxaca: Bahía La Entrega (HermosoSalazar, 1999, as S. biunguiculatus).

Remarks. Hermoso-Salazar (2009) reviewed material from Nayarit, Colima, and Oaxaca and identified it as S. biunguiculatus. Further revision of this material, however, indicated that it belongs to S. brevispinis. In S. brevispinis the antennular peduncle length is more than 3.5 times its width instead of less than 3 times as in S. biunguiculatus; in the former species the rostrum exceeds 0.5 times the length of the first antennular segment, while almost reaching the distal end of the first antennular segment in the later; the lateral spine of the basicerite exceeds the rostrum in S. brevispinis while it does not exceed the rostrum in S. biunguiculatus; in S. brevispinis the length of the scaphocerite scale is about 2.5 times longer than the width, whereas in $S$. biunguiculatus it is less than twice its width.

Synalpheus digueti Coutière, 1909

Material examined. One male (CL $3.1 \mathrm{~mm}$ ), Isla Pajarera, 7 Mar 2013, snorkel, 2 m, rocks, LEMA-CCR108. 2 males (CL $3.3 \mathrm{~mm}$ ), Isla Cocinas, 28 Nov 2011, snorkel, $2 \mathrm{~m}$, polychaetetube reef,LEMA-CCR109. 1 male (CL $4.5 \mathrm{~mm}$ ), Novillos, $5 \mathrm{Mar}$ 2013, scuba diving, $4 \mathrm{~m}$, rocks, LEMA-CCR110. 2 males (CL $4.8 \mathrm{~mm}$ ), 1 ovigerous female (CL $4.7 \mathrm{~mm}$ ), Isla Cocinas, $28 \mathrm{Nov}$ 2011, scuba diving, $5 \mathrm{~m}$, rocks, LEMA-CCR116. 1 male (CL $2.2 \mathrm{~mm}$ ), Isla Cocinas, 5 Mar 2013, snorkel, $3 \mathrm{~m}$, polychaetetube reef, LEMA-CCR161. 1 male (CL $5.1 \mathrm{~mm}$ ), 1 ovigerous female (CL 5.0 mm), Isla Pajarera, 27 Jun 2013, snorkel, 4 m, Pocillopora coral, LEMA-CCR163.

Previous records in Mexico. Gulf of California, Baja California Sur: Bahía La Paz (Hermoso-Salazar, 2009), Bahía Concepción (Carvacho \& Ríos, 1982; Ríos, 1992; Steinbeck \& Ricketts, 1941), Banco Arena (Chace, 1937), Cabo Pulmo (Steinbeck \& Ricketts, 1941; Carvacho \& Ríos, 1982), Isla Coronado, Isla Carmen, Isla Danzante (Hernández et al., 2009), Isla San José (Coutière, 1909; Hermoso-Salazar, 2009; VillalobosHiriart, 2000; Villalobos-Hiriart et al., 1989), Isla Espíritu Santo, Isla Cerralvo (Hermoso-Salazar, 2009; Villalobos-Hiriart et al., 1989; Villalobos-Hiriart, 2000). Sonora: Guaymas (Ríos, 1992; Wicksten, 1983), Isla Tiburón (Hermoso-Salazar,
2009; Villalobos-Hiriart, 2000; Villalobos-Hiriart et al., 1989). Sinaloa: Topolobampo (Hermoso-Salazar, 2009), Punta Chile (Hendrickx, Wicksten, \& van der Heiden, 1983; HermosoSalazar, 2009), Bahía de Mazatlán (van der Heiden \& Hendrickx, 1979), Isla Lobos (Hermoso-Salazar, 2009), Isla Pájaros (Hendrickx et al., 1983; Hendrickx, 1994; Hermoso-Salazar, 2009), Puerto Viejo, harbor entrance Mazatlán (HermosoSalazar, 2009), southern Sinaloa (Hendrickx, 1993b). Nayarit: Punta Los Chivos, Bahía Chacala, Punta de Mita, Isla Isabel (Camacho, 1996; Hermoso-Salazar, 2009), Isla María Madre (Hermoso-Salazar, 2009) Colima: Bahía Santiago, Manzanillo (Hermoso-Salazar, 2009), Isla Clarión (Hernández-Aguilera \& Martínez-Guzmán, 1992; Hermoso-Salazar, 2009). Oaxaca: Bahía La Entrega, Bahía Santa Cruz (Hermoso-Salazar, 2009).

Remarks. Hermoso-Salazar (2009) mentioned that 2 different species have probably been identified under the name of S. digueti. Synalpheus sp. (infra) recorded in this contribution seems to belong to an undescribed species very close to $S$. digueti.

\section{Synalpheus fritzmuelleri Coutière, 1909}

Material revised. 2 females (CL 2.4-2.8 mm), 1 ovigerous female (CL $3.4 \mathrm{~mm}$ ), Novillos, 5 Mar 2013, scuba diving, $4 \mathrm{~m}$, Pocillopora coral, LEMA-CCR124.

Previous records in Mexico. Baja California, Gulf of California (Coutière, 1909).

Remarks. The specimens collected in Bahía Chamela match the description provided for the holotype and lectotype revised by Hermoso-Salazar (2009). However, a molecular analysis seems necessary to determine the status of this amphiamerican species which was described from the eastern Atlantic and is widespread in this region, from North Carolina to Brazil (Macdonald, Ríos, \& Duffy, 2006).

Synalpheus lani Hermoso \& Álvarez, 2005

Material examined. One male (CL $2.1 \mathrm{~mm}$ ), 1 ovigerous female (CL $3.0 \mathrm{~mm}$ ), Isla Cocinas, 28 Nov 2011, scuba diving, $5 \mathrm{~m}$, rocks, LEMA-CCR106. 1 male (CL $1.8 \mathrm{~mm}$ ), Novillos, 28 Nov 2011, scuba diving, $4 \mathrm{~m}$, Pocillopora coral, LEMACCR107. 1 female (CL $2.5 \mathrm{~mm}$ ), Novillos, 05 Mar 2013, scuba diving, $5 \mathrm{~m}$, Pocillopora coral, LEMA-CCR139. 1 female (CL $1.2 \mathrm{~mm}$ ), Isla Cocinas, 5 Mar 2013, snorkel, $2 \mathrm{~m}$, polychaetetube reef, LEMA-CCR162.

Previous records in Mexico. Gulf of California: Nayarit: Punta de Mita, Estero San Cristobal, Playa Pescadores, Isla Isabel, Isla Peña (Hermoso \& Álvarez, 2005; Hermoso-Salazar, 2009).

Remarks. The material from Bahía Chamela is the third record for this species since its description and represents a new southernmost distribution limit.

\section{Synalpheus lockingtoni Coutière, 1909}

Material examined. Four juveniles (CL $1.5 \mathrm{~mm}$ ), Isla Cocinas, 5 Mar 2013, snorkel, 3 m, dead coral, LEMA-CCR120. 5 juveniles, Isla Cocinas, 5 Mar 2013, snorkel, $2 \mathrm{~m}$, polychaetetube reef, LEMA-CCR155. 
Previous records in Mexico. West coast of Baja California Sur: Scammon's Lagoon, Bahía Magdalena (Wicksten, 1983). Gulf of California, Baja California: north of the Gulf of California (Brusca, 1980), San Felipe (Wicksten, 1983). Baja California Sur: Puerto Mulege (Lockington, 1878), Puerto Escondido (Coutière, 1909; Lockington, 1878; Rodríguez-de la Cruz, 1987), Bahía La Paz (Hermoso-Salazar, 2009). Sonora: Bahía Cholla (Wicksten, 1983), Isla San Nicolas (Coutière, 1909; Hermoso-Salazar, 2009). Sinaloa: southern Sinaloa. Nayarit: Punta de Mita (Hermoso-Salazar, 1999, 2009). Guerrero: Zihuatanejo (Wicksten, 1983). Oaxaca: Bahía La Entrega (Hermoso-Salazar, 1999, 2009).

Remarks. The material collected in this study represents the third record for this species found to the south of the Gulf of California where it is abundant (Brusca, 1980).

\section{Synalpheus nobilii (Coutière, 1909)}

Material examined. Two females (CL 1.6-2.3 mm), Isla Cocinas, 28 Nov 2011, scuba diving, 5 m, rocks, LEMA-CCR117. 1 male (CL $3.0 \mathrm{~mm}$ ), 2 females (CL 3.1-3.4 mm), Novillos, 28 Nov 2011, scuba diving, $5 \mathrm{~m}$, Pocillopora coral, LEMACCR118. 6 males (CL 2.3-4.2 mm), 8 females (CL 1.4-2.8 mm), 2 ovigerous females (C $2.5-4.8 \mathrm{~mm}$ ), Isla Cocinas, $5 \mathrm{Mar}$ 2013, snorkel, $3 \mathrm{~m}$, polychaete-tube reef, LEMA-CCR119. 6 males (CL 2.7-4.0 mm), 6 females (CL 2.2-3.4 mm), Isla Pajarera, 7 Mar 2013, snorkel, $3 \mathrm{~m}$, dead coral, LEMA-CCR121. 2 males (CL $2.8 \mathrm{~mm}$ ), 4 females (CL 3.2-3.9 mm), $3 \mathrm{NS}$, NM, Isla Cocinas, 28 Nov 2011, snorkel, $2 \mathrm{~m}$, polychaetetube reef, LEMA-CCR122. 2 females (CL 3.2-4.2 mm), 1 ovigerous female (CL $4.3 \mathrm{~mm}$ ), Isla Cocinas, 28 Nov 2011, snorkel, $2 \mathrm{~m}$, polychaete-tube reef, LEMA-CCR123. 2 males (CL 3.1-3.3 mm), Isla Pajarera, 26 Jun 2013, scuba diving, $7 \mathrm{~m}$, coral, LEMA-CCR132. 1 male (CL $3.9 \mathrm{~mm}$ ), 1 female (CL $2.2 \mathrm{~mm}$ ), Novillos, 5 Mar 2013, scuba diving, $4 \mathrm{~m}$, Pocillopora coral, LEMA-CCR141. 2 males (CL 3.0-3.2 mm), Isla Pajarera, 25 Jun 2013, snorkel, 4 m, Pocillopora coral, LEMA-CCR158. 1 male (CL $5.2 \mathrm{~mm}$ ), 1 ovigerous female (CL $6.2 \mathrm{~mm}$ ), Isla Pajarera, 27 Jun 2013, snorkel, 4 m, Pocillopora coral, LEMACCR164.

Previous records in Mexico. Gulf of California, Baja California Sur: Bahía La Paz, Bahía Chileno (Hermoso-Salazar, 2009), Isla Danzante (Hernández et al., 2009), Isla Espíritu Santo (Wicksten, 1983; Hermoso-Salazar, 2009), Isla Cerralvo (Villalobos-Hiriart et al., 1989; Hermoso-Salazar, 2009); West coast of Baja California Sur: Rocas Alijos (Wicksten, 1996). Sonora: Bahía Santa Catalina, Guaymas (Wicksten, 1983). Sinaloa: Punta Delfín (Hendrickx, 1994), Punta Chile (Hendrickx et al., 1983; Hermoso-Salazar, 2009; van der Heiden \& Hendrickx, 1979; Wicksten, 1983), Cerro del Vigía (Hendrickx, 1994; Hendrickx et al., 1983; van der Heiden \& Hendrickx, 1979; Wicksten, 1983, Mazatlán harbor (Hermoso-Salazar, 2009), Bahía de Mazatlán (Hendrickx et al., 1983; Hermoso-Salazar, 2009; van der Heiden \& Hendrickx, 1979; Wicksten, 1983), southern Sinaloa (Hendrickx, 1993b), Isla Lobos, Isla Pájaros (Hermoso-Salazar, 2009). Nayarit: Estero San Cristóbal, Bahía Chacala, Punta de Mita, Isla
Isabel (Camacho, 1996; Hermoso-Salazar, 2009), Isla María Madre (Hermoso-Salazar, 1999, 2009; Hernández-Aguilera \& Martínez-Guzmán, 1992), Islas Tres Marías (HermosoSalazar, 2009). Jalisco: Barra de Navidad (Álvarez-del Castillo et al., 1992; Hermoso-Salazar, 2009). Colima: Bahía Santiago, Manzanillo (Hermoso-Salazar, 1999, 2009), Isla Socorro (Hermoso-Salazar, 1999, 2009; Wicksten, 1983), Isla Clarión (Hermoso-Salazar, 1999, 2009; Hernández-Aguilera \& Martínez-Guzmán, 1992; Wicksten, 1983). Guerrero: Roca San Lorenzo, Bahía Santa Lucia, Acapulco. Oaxaca: Bahía San Agustín, Bahía La Entrega, Bahía Santa Cruz (Hermoso-Salazar, 2009), Tangola-Tangola (Wicksten, 1983).

Remarks. Synalpheus nobilii is one of the most abundant species of Alpheidae in the Mexican Pacific.

\section{Synalpheus paulsonoides Coutière, 1909}

Material examined. One female (CL $2.0 \mathrm{~mm}$ ), off Isla Cocinas, 27 Jun 2013, dredge, 8 m, sand, LEMA-CCR135.

Previous records in Mexico. West coast of Baja California Sur: Puerto Escondido (Wicksten, 1983). Gulf of California: Isla San José (Coutière, 1909), Isla San Francisco (Wicksten, 1983). Sinaloa: Bahía San Ignacio (Wicksten, 1983). Michoacán: Caleta de Campos (Hermoso-Salazar \& Hernández-Alcántara, 2001).

Remarks. The specimen collected represents the second record south of the Gulf of California and confirms the presence of this species between the Gulf of California and Michoacán.

Synalpheus sanjosei Coutière, 1909

Material examined. One female (CL $4.7 \mathrm{~mm}$ ), Isla Pajarera, 27 Jun 2013, snorkel, 4 m, Pocillopora coral, LEMA-CCR165.

Previous records in Mexico. Isla San José (Coutière, 1909; Hermoso-Salazar, 2009). Sinaloa: Topolobampo (HermosoSalazar, 2009), Teacapán (Hermoso-Salazar, 2009). Nayarit: Punta de Mita. Colima: Bahía Santiago, Manzanillo (HermosoSalazar, 2009). Guerrero: Roca San Lorenzo, Bahía de Santa Lucia, Acapulco (Hermoso-Salazar, 2009). Oaxaca: Bahía La Entrega, Bahía Santa Cruz (Hermoso-Salazar, 2009).

Remarks. Synalpheus sanjosei closely resembles S. superus Abele \& Kim, 1989, S. stylopleuron Hermoso-Salazar \& Hendrickx, 2006, and S. wickstenae Hermoso-Salazar \& Hendrickx, 2006. However, several diagnostic characters allow for the separation of these species, including the shape of the rostroventral process, the length of the lateral spine of the scaphocerite in relation to the length of the antennular peduncle, the length of the lateral spine of the basicerite in relation to the length of the first antennular segment, and the length/width ratio of the propodus of the third pair of pereiopods (HermosoSalazar, 2009).

\section{Synalpheus sp.}

Material examined. Three males (CL 2.5-3.6 mm), 1 female (CL $3.4 \mathrm{~mm}$ ), 1 ovigerous female (CL $4.2 \mathrm{~mm}$ ), Isla Cocinas, 28 Nov 2011, scuba diving, 5 m, rocks, LEMA-CCR96. 1 male (CL $2.8 \mathrm{~mm}$ ), Novillos, 28 Nov 2011, scuba diving, $4 \mathrm{~m}$, Pocillopora coral, LEMA-CCR97. 2 males (CL $2.5 \mathrm{~mm}$ ), 1 female (CL 
$2.1 \mathrm{~mm}$ ), Isla Cocinas, 5 Mar 2013, snorkel, $3 \mathrm{~m}$, polychaetetube reef, LEMA-CCR98. 1 male (CL $2.5 \mathrm{~mm}$ ), Isla Cocinas, 28 Nov 2011, snorkel, 5 m, rocks, LEMA-CCR102. 1 female (CL $3.5 \mathrm{~mm}$ ), Isla Pajarera, 27 Jun 2013, snorkel, $4 \mathrm{~m}$, Pocillopora coral, LEMA-CCR126. 1 male (CL $3.3 \mathrm{~mm}$ ), 1 ovigerous female (CL $2.9 \mathrm{~mm}$ ), Isla Pajarera, 26 Jun 2013, scuba diving, $7 \mathrm{~m}$, rocks, LEMA-CCR128.

Remarks. The specimens examined present a strong morphological resemblance to $S$. digueti, but they can be separated by the cheliped color pattern and the shape of the major cheliped distal margin. In Synalpheus sp. the last segment of the third maxilliped, the distal third of the major cheliped, and the dactyl and fixed finger in the minor cheliped are pink, while in $S$. digueti the last segment of the third maxilliped is blue, the distal third of the major cheliped is red, and the dactyl and fixed finger of the minor cheliped are olive. In addition, Synalpheus sp. lacks the lobule which flanks the spine located on the dorsodistal margin of the major cheliped in S. digueti.

Family Hippolytidae Spence-Bate, 1888

Hippolyte williamsi Schmitt, 1924

Material examined. One male, NM, 4 juveniles, Isla Pajarera, 7 Mar 2013, snorkel, 2 m, rocks, LEMA-CCR146. 2 juveniles, NM, Isla Cocinas, 5 Mar 2013, snorkel, $3 \mathrm{~m}$, polychaete-tube reef, LEMA-CCR153. 1 juvenil, NM, Isla Cocinas, 5 Mar 2013, scuba diving, $9 \mathrm{~m}$, gorgonian coral, LEMA-CCR167. 1 NS, NM, off Isla San Pedro, 26 Jun 2013, dredge, 7 m, sand, LEMACCR203.

Previous records in Mexico. West coast of Baja California Sur: Punta Abreojos (Pereyra \& Sánchez, 2000). Gulf of California, Baja California Sur: Bahía Santa Inés (Chace, 1937), Bahía Concepción (Murtaugh \& Hernández, 2014), Bahía La Paz (Hendrickx, 1994), Isla Montserrat (Villalobos-Hiriart et al., 1989). Sinaloa: southern Sinaloa (Hendrickx et al., 1983). Guerrero: Zihuatanejo (Wicksten, 1983). Nayarit: Punta de Mita (Hendrickx \& Wicksten, 2011), Isla María Madre (HermosoSalazar, 1999). Throughout the Gulf of California (Wicksten, 1983).

Remarks. Although all specimens collected in this study were juveniles, morphological characters fit well with the description of $H$. williamsi. Compared with adult specimens, the rostrum in juveniles is shorter ( 0.5 vs. 0.6 to $0.7 \mathrm{CL}$ ), it is armed with only 1 dorsal tooth ( 3 in adults) and the ventral margin is unarmed or bears only 1 tooth ( 2 in adults).

Latreutes antiborealis Holthuis, 1952

Material examined. One male (NM), 1 ovigerous female (NM), Isla Pajarera, 7 Mar 2013, snorkel, 2 m, dead coral, LEMA-CCR144.

Previous records in Mexico. West coast of Baja California Sur: Bahía Santa María (Wicksten, 1983). Gulf of California, Sonora: Punta Peñasco, Ensenada de San Francisco (Wicksten, 1983). Sinaloa: Bahía de Mazatlán (Hendrickx, 2005; Hendrickx et al., 1983; Wicksten, 1983). Michoacán: Caleta de Campos (Hermoso-Salazar \& Hernández-Alcántara, 2001). Chiapas: Puerto Madero (Rodríguez-Almaraz et al., 2000).
Remarks. Latreutes antiborealis is one of the caridean shrimps with major geographical distribution in the eastern Pacific, from Mexico to Chile. This is the third record south of the Gulf of California and the only one between the Gulf and Michoacán.

Thor algicola Wicksten, 1987

Material examinado. 2 males (CL $1.4 \mathrm{~mm}$ ), 8 ovigerous females (CL 1.3-1.5 mm), 3 juveniles, Isla Cocinas, 5 Mar 2013, snorkel, 2 m, polychaete-tube reef, LEMA-CCR65. 2 males (CL $1.1 \mathrm{~mm}$ ), 1 female (CL $1.2 \mathrm{~mm}$ ), Isla Cocinas, 28 Nov 2011, snorkel, $2 \mathrm{~m}$, rocks, LEMA-CCR69. 1 male (CL $1.0 \mathrm{~mm}$ ), 2 ovigerous females (CL 1.5 mm), 7 Mar 2013, Isla Pajarera, snorkel, $2 \mathrm{~m}$, rocks, LEMA-CCR73. 1 male (CL $1.1 \mathrm{~mm})$, Isla Cocinas, 5 Mar 2013, snorkel, 3 m, dead coral, LEMA-CCR90. 2 males (CL $1.0 \mathrm{~mm}$ ), 2 females (CL $0.8 \mathrm{~mm}$ ), Isla Cocinas, 5 Mar 2013, snorkel, 2 m, polychaete-tube reef, LEMA-CCR93. 2 ovigerous females (CL $1.7 \mathrm{~mm}$ ), Novillos, 5 Mar 2013, scuba diving, 4 m, Pocillopora coral, LEMA-CCR140.

Previous records in Mexico. Gulf of California, Baja California: Laguna Percebú (Ríos \& Carvacho, 1982). Baja California Sur: Bahía Concepción (Murtaugh \& Hernández, 2014; Ríos \& Carvacho, 1982), Pichilingue (Hendrickx, 1994; Hendrickx et al., 1983), Isla Coronado, Isla Candelero (Hernández et al., 2009), Isla San José (Villalobos-Hiriart et al., 1989), Isla Espíritu Santo (Villalobos-Hiriart et al., 1989; Wicksten, 1987), Isla Cerralvo (Villalobos-Hiriart et al., 1989), Gulf of California (Wicksten, 1983). Sonora: Bahía La Choya (Ríos \& Carvacho, 1982; Wicksten, 1987), Bahía San Carlos (Wicksten, 1987), Guaymas (Hendrickx \& Wicksten, 2011; Wicksten, 1987), Punta Doble, Isla Tiburón, Isla San Pedro Nolasco, Isla San Nicolas, Isla Candelero (Wicksten, 1987). Sinaloa: Bahía de Mazatlán (Hendrickx, 1994; Hendrickx et al., 1983), southern Sinaloa (Hendrickx, 1993b). Nayarit: Bahía Chacala (Camacho, 1996), Punta de Mita (Hendrickx \& Wicksten, 2011; HermosoSalazar, 1999), Isla Isabel (Camacho, 1996), Isla María Madre (Hermoso-Salazar, 1999), Islas Tres María (Chace, 1972; Wicksten, 1987). Colima: Bahía Santiago, Manzanillo, Isla Clarión (Hermoso-Salazar, 1999). Guerrero: Zihuatanejo, Acapulco (Wicksten, 1983, 1987). Oaxaca: Bahía Santa Cruz (Hendrickx \& Wicksten, 2011; Hermoso-Salazar, 1999).

Thor cocoensis Wicksten \& Vargas, 2001

Material examined. Two males (NM), Isla Pajarera, 7 Mar 2013, snorkel, 2 m, rocks, LEMA-CCR145.

Previous records in Mexico. None.

Remarks. Thor cocoensis has only been recorded from the type locality and the Islas Galápagos. When compared with the original description and the figures provided by Wicksten and Vargas (2001), small differences were observed in our specimens. Both specimens from Bahía Chamela featured 3 teeth on the rostrum in lieu of 1 or 2 , and uropods are longer than the telson while these are shorter in T. cocoensis. However, we consider these differences to represent morphological variations of this species. This is the first record since its description and for Mexico. The northernmost distribution limit of this species is increased by approximately $14^{\circ}$ latitude. It also represents a new, shallow bathymetric record $(2 \mathrm{~m})$. 
Thor cordelli Wicksten, 1996

Material examined. One female (CL $0.6 \mathrm{~mm}$ ), Isla San Agustín, 29 Nov 2013, scuba diving, 9 m, rocks, LEMA-CCR70.

Previous records in Mexico. West coast of Baja California Sur: Punta Abreojos (Pereyra \& Sánchez, 2000), Rocas Alijos. Gulf of California, Baja California Sur: Isla Danzante (Hernández et al., 2009). Colima: Isla Clarión (Wicksten, 1996).

Remarks. As in the case of $T$. cocoensis, this species may have been overlooked in previous surveys or confused with the widespread and apparently abundant $T$. algicola. The presence of 3 species of Thor in a limited area such as Bahía Chamela indicates that both cocoensis and cordelli could be much more frequent than expected along the Mexican Pacific. A detailed review of the specimens previously reported under the name algicola is therefore needed.

Superfamily Palaemonoidea Rafinesque, 1815

Family Gnathophyllidae Dana, 1852

Gnathophyllum panamense Faxon, 1893

Material examined. One female (CL $2.3 \mathrm{~mm}$ ), Isla San Agustín, 29 Nov 2011, scuba diving, 9 m, rocky sustrate, LEMACCR59. 1 male (CL 1.6 mm), Novillos, 5 Mar 2013, scuba diving, $4 \mathrm{~m}$, Pocillopora coral, LEMA-CCR60.

Previous records in Mexico. Gulf of California, Baja California Sur: Bahía Concepción (Foster et al., 2007; Murtaugh \& Hernández, 2014), Cabo Pulmo (Brusca \& Thomson, 1975), Cabeza Ballena (Wicksten, 1983), Isla Montserrat, Isla San José, Isla Partida, Isla Cerralvo (Villalobos-Hiriart et al., 1989), Isla Espíritu Santo (Villalobos-Hiriart et al., 1989; Wicksten, 1983), Isla Danzante (Hernández et al., 2009). Sonora: Guaymas (Hendrickx \& Wicksten, 2011), Bahía Venetia, Isla San Jorge, Isla San Esteban, Isla San Nicolás (Wicksten, 1983). Sinaloa: Punta Los Cerritos (Hendrickx et al., 1983; Wicksten, 1983), Punta Chile (Hendrickx, 1994), Isla Lobos, Isla Venados (Arzola-González et al., 2010; Hendrickx, 1994), Isla Pájaros, Bahía Mazatlán (Hendrickx, 1994). Nayarit: Punta de Mita (Camacho, 1996; Hermoso-Salazar, 1999), Isla Isabel (Camacho, 1996).

Remarks. The material examined represents the first Mexican record south of the Gulf of California.

Family Palaemonidae Rafinesque, 1815

Subfamily Palaemoninae Rafinesque, 1815

Fennera chacei Holthuis, 1951

Material examined. One ovigerous female (CL $0.9 \mathrm{~mm}$ ), Isla Cocinas, 5 Mar 2013, snorkel, 3 m, Pocillopora coral, LEMACCR61.

Previous records in Mexico. Gulf of California, Baja California Sur: off Los Islotes, Bahía La Paz, Canal San Lorenzo (Hernández et al., 2009; Wicksten \& Hernández, 2000). Nayarit: Isla Isabel (Camacho, 1996; Holthuis, 1951), Islas Marietas. Guerrero: Punta Ixtapa (Hernández et al., 2013).

Remarks. This is one of the smaller species collected during this study. Fennera chacei has been reported 4 times for the Mexican Pacific. This material represents the second record in Mexico south of the Gulf of California, and the first for Jalisco.
Harpiliopsis depressa (Stimpson, 1860)

Material examined. Two males (CL 3.9-4.9 mm), 2 females (CL 4.8-5.2 mm), 2 ovigerous females (CL 4.0-4.4 mm), 1 juvenil, Isla Pajarera, 27 Jun 2013, 4 m, snorkel, Pocillopora coral, LEMA-CCR85. 1 male (CL 2.3 mm), Isla Cocinas, 5 Mar 2013, snorkel, 3 m, Pocillopora coral, LEMA-CCR91.

Previous records in Mexico. Gulf of California, Baja California Sur: Banco Arena (Chace, 1937), Punta Chileno, Roca Shepard's, Cabo San Lucas (Wicksten, 1983), Bahía La Paz (Hernández et al., 2008), Isla Santa Cruz, Isla San José (Villalobos-Hiriart et al., 1989), Isla Espíritu Santo (Holthuis, 1951; Villalobos-Hiriart et al., 1989; Wicksten, 1983), Isla Ballena (Rodríguez-de la Cruz, 1987), Isla Cerralvo (VillalobosHiriart et al., 1989), Isla Coronado (Hernández et al., 2009). Nayarit: Punta de Mita (Camacho, 1996; Hermoso-Salazar, 1999), Isla Isabel (Camacho, 1996; Holthuis, 1951; Wicksten, 1983), Isla María Madre (Hermoso-Salazar, 1999; HernándezAguilera \& Martínez-Guzmán, 1992; Holthuis, 1951), Isla María Cleofas (Wicksten, 1983), Islas Marietas (Hernández et al., 2013). Colima: Bahía Santiago, Manzanillo (HermosoSalazar, 1999), Isla Socorro (Hermoso-Salazar, 1999; Holthuis, 1951), Isla Clarión (Hernández-Aguilera \& Martínez-Guzmán, 1992; Holthuis, 1951). Oaxaca: Bahía La Entrega (HermosoSalazar, 1999), El Maguey (Hernández et al., 2013).

Remarks. Among the characters that permit to differentiate $H$. depressa from $H$. spinigera is the color. Photographs of freshly collected specimens are provided herein to aid in distinguishing the 2 species (Fig. 2). Wicksten and Hernández (2000) have described the color pattern of these 2 species.

\section{Harpiliopsis spinigera (Ortmann, 1890)}

Material examined. One male (CL $2.5 \mathrm{~mm}$ ), 2 females (CL 1.8-2.5 mm), Novillos, 5 Mar 2013, scuba diving, $4 \mathrm{~m}$, rocks, LEMA-CCR64. 1 male (CL $1.6 \mathrm{~mm}$ ), 1 female (CL $2.1 \mathrm{~mm}$ ), Chamela, 6 Mar 2013, gillnet, Pocillopora coral, LEMACCR74.4 males (CL 2.5-3.6 mm), 1 female (CL $4.1 \mathrm{~mm}$ ), 2 ovigerous females (CL 4.3-5.1 mm), 27 Jun 2013, Isla Pajarera, snorkel, 3-5 m, Pocillopora coral, LEMA-CCR84. 1 male (CL $1.1 \mathrm{~mm}$ ), off Isla Cocinas, 27 Jun 2013, dredge, $7 \mathrm{~m}$, sand, LEMA-CCR142.

Previous records in Mexico. Gulf of California, Baja California Sur: Calerita, Los Islotes, Bahía La Paz (Hernández et al., 2008, 2009; Wicksten \& Hernández, 2000), Isla Coronados (Hernández et al., 2009), Bahía San Gabriel, Isla Espíritu Santo (Wicksten \& Hernández, 2000). Nayarit: Islas Marietas. Oaxaca: Estacahuite (Hernández et al., 2013).

Remarks. Harpiliopsis spinigera was first reported from the Gulf of California, in the Mexican Pacific, by Wicksten and Hernández (2000). More recents records were provided by Hernández et al. (2009, 2013). According to Wicksten and Hernández (2000), their specimens closely fit the description of Chace and Bruce (1993). In the diagnosis of Harpiliopsis, Chace and Bruce (1993) mentioned "abdomen with pleuron of fifth somite sharp-pointed". However, in our specimens both the fourth and the fifth somites are rounded. The material identi- 


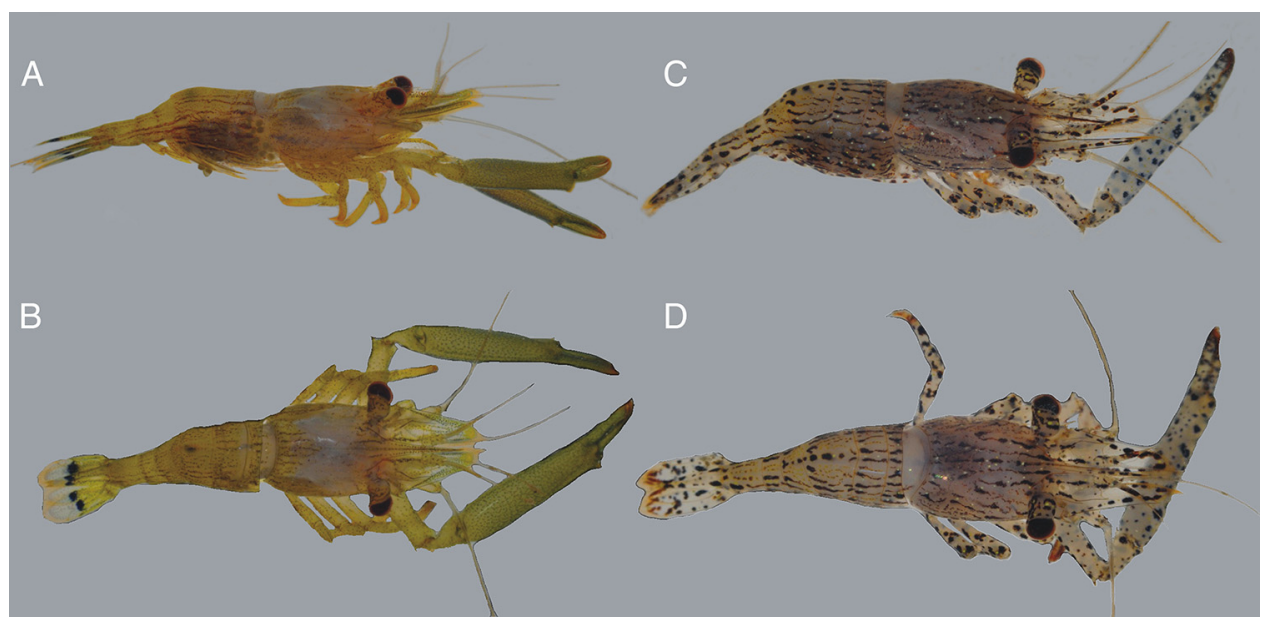

Figure 2. Color patterns of freshly collected specimens of Harpiliopsis depressa (A and B) and H. spinigera (C and D) from Bahía Chamela.

fied by Hernández et al. (2013) as H. spinigera and deposited in the Invertebrate Collection at the Mazatlán Marine Station was examined. All the specimens feature a rounded posterior margin in the fourth and fifth somites as in our specimens. Wicksten (1983) mentioned that the specimens of H. depressa offered a considerable variation in the abdominal spination. Based on the examination of freshly collected material, Wicksten and Hernández (2000) reported 2 species from the Gulf of California ( $H$. depress $a$ and $H$. spinigera), thus indicating that the variation observed by Wicksten (1983) in H. depressa could be due to the fact that she was actually working with material of both species. A molecular analysis would most likely solve this problem and indicate if specimens of $\mathrm{H}$. spinigera from different localities within its distribution range belong to 1 or 2 species.

\section{Macrobranchium tenellum (Smith, 1871)}

Material examined. One male (CL $3.3 \mathrm{~mm}$ ), Estero Pérula, 29 Nov 2011, by hand, 0.5 m, LEMA-CCR72.

Previous records in Mexico. Gulf of California, Baja California Sur: Mulegé, Bahía La Paz. Sinaloa: Estero El Verde, Laguna Caimanero, Mazatlán (Hendrickx, 1994; Hendrickx \& Wicksten, 2011; Hendrickx et al., 1983; Holthuis, 1952; van der Heiden \& Hendrickx, 1979; Wicksten, 1983). Guerrero: Laguna de Mitla, Laguna de Coyuca, Laguna de Tres Palos, Laguna de Chautengo (Holthuis, 1952; Román, 1979, 2004; Wicksten, 1983). Oaxaca: Bahía Tangola-Tangola (Holthuis, 1952; Wicksten, 1983).

Remarks. As pointed out by Hendrickx and Wicksten (2011), M. tenellum is of the few species of the genus that occur in estuaries and coastal lagoons, where the salinity can reach values higher than $22 \%$. This record for Jalisco reaffirms the fact that M. tenellum is the species of the genus with the greatest number of records in coastal ecosystems along the west coast of Mexico.

\section{Neopontonides henryvonprahli Ramos, 1995}

Material examined. One male (CL $1.5 \mathrm{~mm}), 1$ ovigerous female (CL $1.6 \mathrm{~mm}$ ), Isla Colorada, 4 Mar 2013, scuba diving, $9 \mathrm{~m}$, gorgonian coral, LEMA-CCR166.
Previous records in Mexico. Known only from Costa Rica and Colombia (Ramos, 1995).

Remarks. The material recorded from Bahía Chamela is the first for this species since its description, extending the northernmost distribution limit by approximately $16^{\circ}$ of latitude. It also represents a new maximum depth record (from 6 to $9 \mathrm{~m}$ ). Ramos (1995) mentioned that Neopontonides henrivronprahli is a symbiont of the gorgonians Muricea robusta Verril, 1866 and Leptogorgia alba (Duchassaing and Michelotti, 1864), while our specimens were found associated to Leptogorgia exigua Verril, 1870.

\section{Palaemon ritteri Holmes, 1895}

Material examined. Six males (CL 2.5-4.2 mm), 3 females (CL 2.6-3.6 mm), 2 ovigerous females (CL $5.3 \mathrm{~mm}$ ), Chamela, 5 Mar 2013, by hand, intertidal, $0.3 \mathrm{~m}$, rock and sand, LEMACCR71.

Previous records in Mexico. West coast of Baja California Sur: Bahía San Bartolomé, Bahía Magdalena (Holthuis, 1952). Gulf of California, Baja California: Estero Punta Banda to Bahía Magdalena (Luke, 1977; Wicksten, 1983), San Felipe to Bahía La Paz (Holthuis, 1952; Wicksten, 1983), Bahía de San Luis Gonzaga, Bahía de los Ángeles (Luke, 1977), Isla Ángel de la Guarda (Holthuis, 1952; Villalobos-Hiriart et al., 1989), Isla Rasa, Isla Salsipuedes, Isla Las Ánimas, Isla San Lorenzo (Villalobos-Hiriart et al., 1989). Baja California Sur: Bahía Santa Inés (Chace, 1937), Bahía Coyote (Luke, 1977), Bahía Concepción (Foster et al., 2007; Murtaugh \& Hernández, 2014; Steinbeck \& Ricketts, 1941), Bahía Agua Verde (Holthuis, 1952), Punta Pequeña (Luke, 1977), Arrecife San Marcial, Mangle Anchorage (Holthuis, 1952), Bahía La Paz (Holthuis, 1952; Rodríguez-de la Cruz, 1987), Punta Los Frailes (Luke, 1977), Cabeza Ballenas, Cabo San Lucas (Holthuis, 1952), Isla San Marcos, Isla Coronado (Villalobos-Hiriart et al., 1989), Isla Carmen (Holthuis, 1952; Villalobos-Hiriart et al., 1989), Isla Monserrat, Isla San José (Villalobos-Hiriart et al., 1989), Isla Espíritu Santo (Luke, 1977; Steinbeck \& Ricketts, 1941; Villalobos-Hiriart et al., 1989), Isla San Francisco (Holthuis, 1952), Isla Partida (Luke, 
1977). Sonora: Puerto Peñasco to Ensenada de Bacochibampo (Hendrickx \& Wicksten, 2011; Wicksten, 1983), Puerto Peñasco (Luke, 1977; Rodríguez-Almaraz et al., 2000), Bahía Tepoca (Holthuis, 1952), Bahía San Carlos (Luke, 1977), Isla Tiburón (Holthuis, 1952; Villalobos-Hiriart et al., 1989), Isla San Esteban (Villalobos-Hiriart et al., 1989), Isla Turners (Holthuis, 1952). Sinaloa: Punta Sábalo (Hendrickx, 1994; Hendrickx \& Wicksten, 1987; Luke, 1977), Bahía de Mazatlán (Hendrickx \& Wicksten, 1987; Luke, 1977), Isla Lobos, Isla Venados (Arzola-González et al., 2010). Nayarit: Chacala (RodríguezAlmaraz et al., 2000), Punta de Mita (Camacho, 1996), Isla María Madre (Hermoso-Salazar, 1999; Hernández-Aguilera \& Martínez-Guzmán, 1992). Jalisco: Bahía de Banderas, Bahía Chamela, Bahía de Tenacatita (López-Uriarte \& Ríos-Jara, 2004). Guerrero: Ixtapa (Rodríguez-Almaraz et al., 2000). Oaxaca: Estacahuite (Martínez-Guerrero, 2007), Puerto Escondido (Rodríguez-Almaraz et al., 2000).

Remarks. A very common species in tidal pools in Bahía Chamela.

Palaemonetes hiltoni Schmitt, 1921

Material examined. One female (CL $1.8 \mathrm{~mm}$ ), off Isla San Pedro, 26 Jun 2013, dredge, $7 \mathrm{~m}$, sand, LEMA-CCR77. $1 \mathrm{NS}$, NM, off Isla Cocinas, 27 Jun 2013, dredge, 8 m, sand, LEMACCR160.

Previous records in Mexico. West coast of Baja California Sur: Punta Abreojos (Pereyra \& Sánchez, 2000). Gulf of California, Sonora: Estero Conic, Canal Infiernillo (Hendrickx, 2008), Guaymas (Holthuis, 1952). Sinaloa: Estero el Verde (Hendrickx, 1994; Hendrickx et al., 1983), Laguna Caimanero (Hendrickx, 1994; Hendrickx et al., 1983; Wicksten, 1983).

Remarks. According to Wicksten (1983), this species is most common in coastal lagoons and estuaries. One of the specimens collected was parasitized by an unidentified bopyrid isopod.

Subfamily Pontoniinae Kingsley, 1879a

Palaemonella holmesi (Nobili, 1907)

Material examined. Two females (CL $2.1 \mathrm{~mm}$ ), Isla San Agustín, 29 Nov 2011, scuba diving, 9 m, rocks, LEMA-CCR75. 1 male (CL $1.6 \mathrm{~mm}$ ), off Isla San Pedro, 26 Jun 2013, dredge, 7 m, LEMA-CCR78A. 1 ovigerous female (CL $2.2 \mathrm{~mm}$ ), off Isla San Pedro, 26 Jun 2013, dredge, 7 m, sand, LEMA-CCR78B. 1 male (CL $2.5 \mathrm{~mm}$ ), 1 ovigerous female (CL $2.5 \mathrm{~mm}$ ), Novillos, 5 Mar 2013, scuba diving, 4 m, coral, LEMA-CCR136. 1 ovigerous female (CL $1.3 \mathrm{~mm}$ ), Isla Pajarera, 26 Jun 2013, scuba diving, $7 \mathrm{~m}$, dead coral, LEMA-CCR137. 1 male (CL $1.1 \mathrm{~mm}$ ), Isla Cocinas, 5 Mar 2013, snorkel, 2 m, polychaete-tube reef, LEMA-CCR159.

Previous records in Mexico. West coast of Baja California Sur: off Cabo Tortola, Bahía Tortuga (Wicksten, 1983), Bahía Magdalena (Chace, 1937; Wicksten, 1983). Gulf of California, Baja California: Cabo San Miguel (Hendrickx, 2001; Hendrickx \& Wicksten, 2011), Rocas Consag, Isla Willard, Isla Ángel de la Guarda (Holthuis, 1951), Isla Las Animas (Wicksten, 1983). Baja California Sur: Bahía Falsa (Rodríguezde la Cruz, 1987), Bahía Santa Inés (Chace, 1937), Bahía Concepción (Holthuis, 1951; Murtaugh \& Hernández, 2014),
Puerto Escondido, Punta Prieta (Holthuis, 1951), Bahía La Paz (Hendrickx, 1994; Hernández et al., 2009; Holthuis, 1951), Cabo San Lucas (Chace, 1937; Holthuis, 1951), Isla Tortuga (Holthuis, 1951), Isla Carmen (Holthuis, 1951; Wicksten, 1983), Isla San José (Villalobos-Hiriart et al., 1989), Isla San Francisco, Isla Partida (Holthuis, 1951), Isla Espíritu Santo (Holthuis, 1951; Rodríguez-de la Cruz, 1987; Villalobos-Hiriart et al., 1989; Wicksten, 1983), Isla Cerralvo (Villalobos-Hiriart et al., 1989), Canal San Lorenzo (Holthuis, 1951). Sonora: off Rocky Point (Holthuis, 1951), El Desemboque (Wicksten, 1983), Isla Tiburón, Isla San Esteban (Holthuis, 1951), Isla Blanca (Wicksten, 1983), Playa Piedras Pintas, Bahía Sendero Viejo, Guaymas (Hendrickx \& Wicksten, 2011). Sinaloa: Bahía Mazatlán (Hendrickx \& Wicksten, 2011). Nayarit: Isla Isabel (Camacho, 1996), Isla María Madre (Holthuis, 1951). Colima: Isla Socorro (Wicksten, 1983), Isla Clarión (Holthuis, 1951).

Remarks. The present records extend the southernmost distribution limit of this species by ca $1.5^{\circ}$ latitude along the coast of the Mexican Pacific.

Periclimenes infraspinis (Rathbun, 1902)

Material examined. One ovigerous female (CL $2.0 \mathrm{~mm}$ ), off Isla San Pedro, 26 Jun 2013, dredge, 7 m, sand, LEMACCR76A. 2 males (CL 1.5-1.8 mm), 1 ovigerous female (CL $1.9 \mathrm{~mm}$ ), same data, LEMA-CCR76B.

Previous records in Mexico. West coast of Baja California: Scammon's Lagoon (Wicksten, 1983). West coast of Baja California Sur: Puerto San Bartolomé (Holthuis, 1951), Bahía Magdalena (Luke, 1977). Gulf of California, Baja California: Bahía San Felipe, Canal San Lorenzo, Bahía San Francisquito, Isla Willard, Isla Ángel de la Guarda (Holthuis, 1951). Baja California Sur: Punta San Marcial (Hendrickx \& Wicksten, 2011), Bahía Santa Inés (Chace, 1937), Puerto Escondido (Holthuis, 1951), Bahía Concepción (Holthuis, 1951; Murtaugh \& Hernández, 2014; Wicksten, 1983), Bahía Agua Verde, Cabo San Lucas, Isla Tortuga, Isla Carmen (Holthuis, 1951), Roca San Marcial (Wicksten, 1983), Isla San José (Holthuis, 1951; Villalobos-Hiriart et al., 1989), Isla San Francisco (Holthuis, 1951), Isla Espíritu Santo (Rodríguez-de la Cruz, 1987). Sonora: Punta Tepoca (Hendrickx \& Wicksten, 2011), Punta Rocosa (Holthuis, 1951), Estero Soldado, Roca Ventana (Wicksten, 1983), Guaymas (Holthuis, 1951). Sinaloa: Bahía Mazatlán (Hendrickx, 1994; Wicksten, 1983).

Remarks. The record from Bahía Chamela is the first south of the Gulf of California, extending the southernmost distribution limit along the coast of the Mexican Pacific by ca $4^{\circ}$ latitude.

Pontonia margarita Smith, 1869

Material examined. One male (CL $6.0 \mathrm{~mm}$ ), 1 ovigerous female (CL5.5 mm), Isla San Pedro, 26 Jun 2013, snorkel, 3-4 m, in Pinctada mazatlanica (Hanley 1856), LEMA-CCR68. 6 males (CL 3.2-5.9 mm), 7 ovigerous females (CL 5.0-6.3 mm), Isla Cocinas, 28 Nov 2011, scuba diving, $5 \mathrm{~m}$, in Pinctada mazatlanica, LEMA-CCR79. 3 males (CL 5.4-6.4 mm), 3 ovigerous females (CL 6.1-8.4 mm), Isla San Agustín, 7 Mar 2013, scuba diving, $8 \mathrm{~m}$, in Pinctada mazatlanica, LEMA-CCR94. 2 NS, NM, Isla Cocinas, 28 Nov 2011, scuba diving, 5 m, in Pinctada 
mazatlanica, LEMA-CCR337. 2 NS, NM, Chamela, collecting date unknown, LEMA-CCR338.

Previous records in Mexico. West coast of Baja California Sur: Punta Santo Domingo (Chace, 1937). Gulf of California, Baja California: Bahía de Las Animas (Villalobos-Hiriart et al., 1989). Baja California Sur: Bahía Santa Inés (Chace, 1937), Bahía Mulegé, Bahía Concepción (Ríos, 1989), Bahía Agua Verde (Fransen, 2002; Holthuis, 1951; Wicksten, 1983), Puerto Escondido (Fransen, 2002; Holthuis, 1951; Wicksten, 1983), Bahía La Paz (Hendrickx, 1994; Rodríguez-de la Cruz, 1987), Arrecife Pulmo (Chace, 1937), Bahía Punto Medio (Holthuis, 1951), Isla Carmen, Isla Montserrat (Villalobos-Hiriart et al., 1989), Isla San José (Fransen, 2002; Holthuis, 1951; VillalobosHiriart et al., 1989), Isla San Francisco (Fransen, 2002; Holthuis, 1951; Wicksten, 1983), Isla Espíritu Santo (Fransen, 2002; Holthuis, 1951; Villalobos-Hiriart et al., 1989; Wicksten, 1983), Isla Cerralvo (Holthuis, 1951; Villalobos-Hiriart et al., 1989), Isla San Lucas (Holthuis, 1951). Sonora: Guaymas (Fransen, 2002; Hendrickx \& Wicksten, 2011), Isla Tiburón (VillalobosHiriart et al., 1989). Sinaloa: Bahía de Mazatlán (Fransen, 2002; Hendrickx, 1994; Hendrickx \& Wicksten, 2011; Hendrickx et al., 1983; van der Heiden \& Hendrickx, 1982), al sur de Sinaloa (Hendrickx, 1993b). Nayarit: Bahía de Chacala, Isla Isabel (Camacho, 1996), Isla María Madre (Fransen, 2002; Holthuis, 1951). Jalisco: Barra de Navidad (Álvarezdel Castillo et al., 1992), Bahía Tenacatita (Fransen, 2002). Colima: Islas Revillagigedo (Fransen, 2002; Holthuis, 1951). Michoacán: Playa Maruata (Ríos, 1989). Oaxaca: Bahía Santa Cruz (Hermoso-Salazar, 1999), Playa La Tijera (MartínezGuerrero \& Hendrickx, 2011).

Remarks. As in the majority of records for this species, all specimens collected at Bahía Chamela were found associated with the bivalve Pinctada mazatlanica.

Pontonia simplex Holthuis, 1951

Material examined. One male (CL $10.1 \mathrm{~mm}$ ), Isla Pajarera, 7 Mar 2013, scuba diving, 8 m, in Pinna rugosa (Sowerby, 1835), LEMA-CCR173.

Previous records in Mexico. Gulf of California, Baja California Sur: Puerto Escondido (Wicksten, 1983). Sinaloa: Teacapán (Martínez-Guerrero \& Hendrickx, 2011). Jalisco: Bahía Tenacatita (Fransen, 2002; Holthuis, 1951; Wicksten, 1983), Isla Puercos (Hendrickx \& Wicksten, 2011).

Remarks. Unlike Pontonia margarita, P. simplex has been rarely collected within its distribution range. Most records are from the Mexican Pacific and only 1 from Panama (Fransen, 2002). This species has been reported as commensal of species of Pinna. Our specimen was collected in Pinna rugosa (Sowerby, 1835).

\section{Typton hephaestus Holthuis, 1951}

Material examined. One female (CL $0.8 \mathrm{~mm}$ ), Isla Cocinas, 05 Mar 2013, snorkel, 2-3 m, in polychaete-tube reef, LEMACCR83.

Previous records in Mexico. West coast of Baja California: Scammon's Lagoon (Wicksten, 1983). Gulf of California, Baja
California Sur: $24^{\circ} 12^{\prime} \mathrm{N}, 109^{\circ} 55^{\prime} \mathrm{W}$ (Holthuis, 1951). Nayarit: Islas Tres Marías (Wicksten \& Hendrickx, 1992).

Remarks. According to the literature, only 4 specimens of this species have been collected to date. The present record from Bahía Chamela extends its southernmost distribution limit by ca $1^{\circ}$ latitude. The material recorded from Barra de Navidad and off Río Suchiate, Gulf of Tehuantepec by Hendrickx and Wicksten (2011) belongs to a different species (T. granulosus Ayón-Parente et al., 2015).

Superfamily Processoidea Ortmann, 1896

Family Processidae Ortmann, 1896

Processa aequimana (Paulson, 1875)

Material examined. One male (CL $2.7 \mathrm{~mm}$ ), 1 ovigerous female (CL $2.6 \mathrm{~mm}$ ), off Isla San Pedro, $7 \mathrm{~m}$, dredge, sand, LEMA-CCR147.

Previous records in Mexico. Gulf of California, Baja California: Punta San Felipe (Wicksten, 1983), Cabo San Miguel (Hendrickx, 1990). Baja California Sur: off Punta Chivato, Isla Carmen (Wicksten, 1983). Sonora: Bahía Tepoca (Wicksten, 1983), Bahía Algodones (Hendrickx \& Wicksten, 2011), Isla San Jorge (Wicksten, 1983), Isla Tiburón (Hendrickx, 1990), Sinaloa: off Río Fuerte, Bahía Santa María (Hendrickx, 1990). Nayarit: Punta de Mita (Hendrickx \& Wicksten, 2011). Chiapas: Gulf of Tehuantepec (Hendrickx, Demestre, Esparza-Haro, \& Salgado-Barragán, 1997).

Remarks. The first record for this species in the Mexican Pacific was documented by Wicksten (1983), who mentioned that the specimen fit well with the description by Hayashi (1975). Material collected from Bahía Chamela represents the second record south of the Gulf of California.

\section{Processa hawaiensis (Dana, 1852)}

Material examinado. One male (CL $1.7 \mathrm{~mm})$, Novillo, 28 Nov 2011, scuba diving, $5 \mathrm{~m}$, rocks, LEMA-CCR63. 3 males (CL 1.1-1.3 mm), Isla Pajarera, 25 Jun 2013, scuba diving, 7 m, rocks, LEMA-CCR62.

Previous records in Mexico. Nayarit: Punta de Mita, Isla Isabel (Álvarez et al., 1996; Ayón-Parente et al., 2012; Camacho, 1996). Jalisco: Bahía Chamela (Ayón-Parente et al., 2012). Colima: Bahía Santiago (Hermoso-Salazar, 1999).

Remarks. Processa hawaiensis is widely distributed in the eastern Pacific, Indo-Pacific, and Indian Ocean. Small morphological differences have been observed in this species (e.g., Chace, 1962; Edmondson, 1946; Hayashi, 1975) and it may represent a species complex occurring throughout its presently recognized distribution range. A thorough morphological revision of material from different localities is needed, including a comparative molecular based analysis to clarify its taxonomic status, as was suggested by Ayón-Parente et al. (2012).

\section{Discussion}

Although the carideans are among the best-known group of crustaceans in the Mexican Pacific, the knowledge for this group of crustaceans in Bahía Chamela is still scarce. Only 8 species 
belonging to 5 genera were recorded previously in the area (López-Uriarte \& Ríos-Jara, 2004). Considering the total number of shrimp collected during this survey (40 species), $90 \%$ of the species are new records for the area, thus increasing species richness by $400 \%$. It is also important to emphasize the presence of $N$. henryvonprahli and T. cocoensis in the Mexican Pacific; both have not been recorded since their original description in Colombia and Costa Rica, respectively. Their geographical range was extended by 16 and $14^{\circ}$ latitude to the north, respectively. As expected, considering the habitats that were sampled during this survey, the Alpheoidea, with 2 families, 6 genera, and 25 species was the best represented, followed by the Palaemonoidea with 2 families, 11 genera, and 13 species, while the Processoidea only included 1 family, 1 genus, and 2 species. The total number of species found during the survey is not surprising since these 3 superfamilies are the best represented in the eastern tropical Pacific region (Wicksten \& Hendrickx, 2003). Compared with the rest of the Mexican Pacific, the number of species found in Bahía Chamela is also high, representing $44 \%$ of the genera and $45 \%$ of the benthic species reported by Hendrickx (1993a) for the Pacific coast of Mexico (Table 1).

When species richness of caridean shrimps found in Bahía Chamela is compared with those recorded from other areas in the Mexican Pacific (Table 2), the number of species is higher than in these localities, including the islands from the Gulf of California (Villalobos-Hiriart et al., 1989). A higher number is proposed for the SE Gulf of California (23 genera and 53 species vs. 18 genera and 40 species) by Hendrickx (1993b), but this number includes a wider depth range and a much longer sampling period. The relatively high diversity of carideans found in Bahía Chamela is most likely due to the great diversity of environments that exist in the locality and to the fact that different sampling methods were used, thus increasing the probability of collecting small, rare and cryptic species. It is surprising that no species of Lysmata were collected during this study, considering that the Bahía Chamela is within the distribution range of several species currently recognized for the eastern tropical Pacific. In addition, samples were obtained in localities and substrate types where these species commonly inhabit. Perhaps the absence of this genus was because the samples were taken during daylight hours, and according to Wicksten (2000) Lysmata species are nocturnal.

The 2 best-represented genera of caridean shrimps from Bahía Chamela (Synalpheus with 10 species and Alpheus with 9 species) are among the most diverse and abundant in tropical oceans (Anker, Ahyong, Noël, \& Palmer, 2006). They
Table 1

List of species of caridean shrimps collected during the survey in Bahía Chamela, Jalisco, Mexico.

\begin{tabular}{|c|c|}
\hline Family & Species \\
\hline Alpheidae & $\begin{array}{l}\text { Alpheus arenensis (Chace, 1937) } \\
\text { Alpheus cylindricus Kingsley, 1878 } \\
\text { Alpheus galapagensis Sivertsen, } 1933 \\
\text { Alpheus lottini Guérin-Méneville, } 1838 \\
\text { Alpheus paracrinitus Miers, } 1881 \\
\text { Alpheus rostratus Kim \& Abele, } 1988 \\
\text { Alpheus sulcatus Kingsley, 1878b } \\
\text { Alpheus utriensis Ramos \& Von Prahl, } 1989 \\
\text { Alpheus wonkimi Anker \& Pachelle, } 2013 \\
\text { Pomagnathus corallinus Chace, } 1937 \\
\text { Synalpheus bannerorum Abele, } 1975 \\
\text { Synalpheus brevispinis Coutière, } 1909 \\
\text { Synalpheus digueti Coutière, 1909 } \\
\text { Synalpheus fritzmuelleri Coutière, } 1909 \\
\text { Synalpheus lani Hermoso-Salazar \& Álvarez, } 2005 \\
\text { Synalpheus lockingtoni Coutière, } 1909 \\
\text { Synalpheus nobilii (Coutière, 1909) } \\
\text { Synalpheus paulsonoides Coutière, } 1909 \\
\text { Synalpheus sanjosei Coutière, 1909 } \\
\text { Synalpheus sp. }\end{array}$ \\
\hline Hippolytidae & $\begin{array}{l}\text { Hippolyte williamsi } \text { Schmitt, } 1924 \\
\text { Latreutes antiborealis } \text { Holthuis, } 1952 \\
\text { Thor algicola Wicksten, } 1987 \\
\text { Thor cocoensis Wicksten \& Vargas, } 2001 \\
\text { Thor cordelli Wicksten, } 1996\end{array}$ \\
\hline Gnathophyllidae & Gnathophyllum panamense Faxon, 1893 \\
\hline Palaemonidae & $\begin{array}{l}\text { Fennera chacei Holthuis, } 1951 \\
\text { Harpiliopsis depressa (Stimpson, 1860) } \\
\text { Harpiliopsis spinigera (Ortmann, 1890) } \\
\text { Macrobranchium tenellum (Smith, 1871) } \\
\text { Neopontonides henryvonprahli Ramos, } 1995 \\
\text { Palaemon ritteri Holmes, } 1895 \\
\text { Palaemonetes hiltoni Schmitt, } 1921 \\
\text { Palaemonella holmesi (Nobili, 1907) } \\
\text { Periclimenes infraspinis (Rathbun, 1902) } \\
\text { Pontonia margarita Smith, } 1869 \\
\text { Pontonia simplex Holthuis, } 1951 \\
\text { Typton hephaestus Holthuis, } 1951\end{array}$ \\
\hline Processidae & $\begin{array}{l}\text { Processa aequimana (Paulson, 1875) } \\
\text { Processa hawaiensis (Dana, 1852) }\end{array}$ \\
\hline
\end{tabular}

are particularly important for studies on symbiosis with other species of vertebrates (e.g., Randall, Lobel, \& Kennedy, 2005) and invertebrates (e.g., Silliman, Layman, \& Altieri, 2003). Species of these 2 genera live in a wide variety of habitats, although they are mostly associated with corals, tidal pools, burrows in sand and muddy substrates, and in symbiosis with

Table 2

Comparison of caridean shrimp species and genera richness reported from different areas in the Mexican Pacific.

\begin{tabular}{|c|c|c|c|}
\hline Area & Genera & Species & Reference \\
\hline Islands from the Gulf of California & 15 & 30 & Villalobos-Hiriart et al., 1989 \\
\hline Isla Clarión & 9 & 22 & Hernández-Aguilera \& Martínez-Guzmán, 1992 \\
\hline Estuario Mulege and Bahía Concepción & 7 & 16 & Ríos, 1992 \\
\hline Laguna de Barra de Navidad & 6 & 11 & Álvarez-del Castillo et al., 1992 \\
\hline SE Gulf of California & 23 & 53 & Hendrickx, 1993b \\
\hline Isla Carmen & 9 & 10 & Rodríguez-Almaraz et al., 2002 \\
\hline Bahía Loreto & 8 & 15 & Holguín-Quiñones, Félix-Pico, \& Villareal-Chávez, 2002 \\
\hline Bahía Chamela & 18 & 40 & This study \\
\hline
\end{tabular}


some invertebrates (Kim \& Abele, 1988). Particularly, in Bahía Chamela these species were found commonly associated with living corals of the genus Pocillopora, polychaete-tube reefs, rocks, and dead corals. One species, S. paulsonoides, was found in sandy substrates. However, the diversity of these snapping shrimp in the area is probably higher and other specific microhabitats (e.g., sponges, sea anemones, ascidians) should be explored in order to detect the presence of more species.

Heterogeneous habitats have the highest diversity of species and hard substrates offer more habitats and protection than soft sediments. Only 8 species were captured in sandy bottoms and the remainder in various types of hard substrates (e.g., rocks, corals, polychaeta reefs). Hendrickx (1993b) also reported a low number of species (9) in sandy shores from the SE Gulf of California. According to Gotelli and Abele (1983), the decapod crustaceans are the most abundant macroinvertebrates associated with Pocillopora corals. In Bahía Chamela, 18 species were found in this habitat, while most other species were found in mixed rocky and coralline substrates. In addition, Hippolyte williamsi and $N$. henryvonprahli were collected on soft corals (Leptogorgia spp.).

\section{Acknowledgements}

The authors thank all students for their help during collection of the samples, and to Jorge Vega, Chief of the Biological Station Chamela, IBUNAM, for all facilities provided during field trips. To Diego Moreno for the photographs. Part of this study was supported by Conabio, Mexico (Project 1452 JF023 "Inventario de la biota marina (cnidarios, poliquetos, moluscos, crustáceos, equinodermos y peces) del Santuario Islas e Islotes de Bahía Chamela, Jalisco, México)". MAP thanks CONACYT, Mexico for the grant (90198) received during his postdoctoral stay and support in the retention and repatriation program in CUCBA, University of Guadalajara.

\section{References}

Abele, L. G. (1975). The macruran decapod Crustacea of Malpelo Island. Smithsonian Contributions to Zoology, 176, 69-85.

Abele, L. G. (1976). Comparative species composition and relative abundance of decapod crustaceans in marine habitats of Panama. Marine Biology, 38, 263-275.

Abele, L. G., \& Kim, W. (1986). An illustrated guide to the marine decapod crustaceans of Florida (Vol. 8). Technical Series, Department of Environmental Regulations.

Ahyong, S. T., Lowry, J. K., Alonso, M., Bamber, R. N., Boxshall, G. A., Castro, P., et al. (2011). Subphylum Crustacea Brünnich, 1772. In Z. Q. Zhang (Ed.), Animal biodiversity: An outline of higher-level classification and survey of taxonomic richness (Vol. 3148) (pp. 1-237). Zootaxa: Monograph.

Álvarez, F., Camacho, M. E., \& Villalobos, J. L. (1996). The first species of Prionalpheus from the eastern Pacific, and new records of caridean shrimp (Crustacea: Decapoda: Caridea) from the western coast of Mexico. Proceedings of the Biological Society of Washington, 109, 715-724.

Álvarez-del Castillo, C. M., Hendrickx, M. E., \& Rodríguez, S. C. (1992). Crustáceos decápodos de la laguna Barra de Navidad, Jalisco, México. Proceedings of the San Diego Society of Natural History, 27, 1-9.

Anker, A., Ahyong, S. T., Noël, P. Y., \& Palmer, A. R. (2006). Morphological phylogeny of alpheid shrimps: Parallel preadaptation and the origin of a key morphological innovation, the snapping claw. Evolution, 60, 2507-2528.
Anker, A., Hurt, C., \& Knowlton, N. (2007). Revision of the Alpheus nuttingi (Schmitt) species complex (Crustacea: Decapoda: Alpheidae), with description of a new species from the tropical eastern Pacific. Zootaxa, 1577, $41-60$.

Anker, A., Hurt, C., \& Knowlton, N. (2008a). Revision of the Alpheus cristulifrons species complex (Crustacea: Decapoda: Alpheidae), with description of a new species from the tropical eastern Atlantic. Journal of the Marine Biological Association of the United Kingdom, 88, 543-562.

Anker, A., Hurt, C., \& Knowlton, N. (2008b). Revision of the Alpheus websteri Kingsley, 1880 species complex (Crustacea: Decapoda: Alpheidae), with revalidation of A. arenensis (Chace, 1937). Zootaxa, 1694, 51-68.

Anker, A., \& Pachelle, P. P. G. (2013). Re-examination of the eastern Pacific and Atlantic material of Alpheus malleator Dana, 1852, with the description of Alpheus wonkimi sp. nov. (Crustacea, Decapoda, Alpheidae). Zootaxa, 3637, 412-431.

Arzola-González, J. F., Flores-Campaña, L. M., \& Vázquez-Cervantes, A. (2010). Crustáceos decápodos intermareales de las islas de la costa de Sinaloa, México. Universidad y Ciencia, 26, 179-193.

Ayón-Parente, M., Hendrickx, M. E., \& Galván-Villa, C. M. (2015). A new species of the genus Typton Costa (Crustacea: Decapoda: Palaemonidae: Pontoniinae) from the eastern tropical Pacific. Zootaxa, 3926, 430-438.

Ayón-Parente, M., Hendrickx, M. E., \& Ríos-Jara, E. (2012). Notes on two species of Processa (Decapoda: Processidae) from the Mexican Pacific Nauplius, 20, 63-73.

Ayón-Parente, M., \& Salgado-Barragán, J. (2013). A new species of the caridean shrimp genus Ogyrides Stebbing, 1914 (Decapoda: Ogyrididae) from the eastern tropical Pacific. Zootaxa, 3683, 589-594.

Banner, A. H., \& Banner, D. M. (1966). Contributions to the knowledge of the alpheid shrimp of the Pacific Ocean. Part X. Collections from Fiji, Tonga, and Samoa. Pacific Science, 201, 145-188.

Banner, D. M., \& Banner, A. H. (1982). The alpheid Shrimp of Australia, Part III: The remaining alpheids, principally the genus Alpheus, and the family Ogyrididae. Records of the Australian Museum, 34, 1-357.

Bastida-Izaguirre, D., Ayón-Parente, M., Salgado-Barragán, J., Galván-Villa, C. M., \& Ríos-Jara, E. (2013). New records of the hermit crabs (Crustacea: Decapoda: Paguroidea) from Chamela Bay Islands Sanctuary, Jalisco, Mexico: With comments about the use of empty shells as habitat. Revista Mexicana de Biodiversidad, 84, 782-791.

Brusca, R. C. (1980). Common interdidal invertebrates of the Gulf of California Tucson: University of Arizona Press.

Brusca, R. C., \& Thomson, D. A. (1975). Pulmo Reef: The only "coral reef" in the Gulf of California. Ciencias Marinas, 2, 37-53.

Camacho, M. E. (1996). Aspectos taxonómicos y distribución geográfica de cinco familias de camarones carídeos (Crustacea: Decapoda), en Nayarit, México Thesis. México, D.F.: Facultad de Ciencias, Universidad Nacional Autónoma de México.

Carvacho, A., \& Ríos, R. (1982). Los camarones carídeos del Golfo de California. II. Catálogo, claves de identificación y discusión biogeográfica. Anales del Instituto de Ciencias del Mar y Limnología, Universidad Nacional Autónoma de México, 9, 279-294.

Chace, F. A., Jr. (1937). The templeton Crocker expedition. VII. Caridean decapod Crustacea from the Gulf of California and the west coast of Lower California. Zoologica, 22, 109-138.

Chace, F. A., Jr. (1962). The non-brachyuran decapod crustaceans of Clipperton Island. Proceedings of the United States National Museum, 113, 605-634.

Chace, F. A., Jr. (1972). The shrimps of the Smithsonian-Bredin Caribbean expeditions with a summary of the West Indian shallow-water species (Crustacea: Decapoda: Natantia). Smithsonian Contributions to Zoology, 98, 1-179.

Chace, F. A., Jr., \& Bruce, A. J. (1993). The caridean shrimps (Crustacea: Decapoda) of the Albatross Philippine Expedition 1907-1910, Part 6: Superfamily Palaemonoidea. Smithsonian Contributions to Zoology, 543, 1-252.

Christoffersen, M. L. (1979). Decapod Crustacea: Alpheoidea. Campagnes de la Calypso au large des côtes Atlantiques del'Amérique du Sud (1961-1962). I. Résultats Scientifiques de la Campagne de la Calypso, 11, 297-377.

Coelho, P. A., de Almeida, A. O., de Souza-Filho, J. F., Bezerra, L. E. A., \& Giraldes, B. W. (2006). Diversity and distribution of the marine and estuarine shrimps (Dendrobranchiata, Stenopodidea and Caridea) from North and Northeast Brazil. Zootaxa, 1221, 41-62. 
Coelho, P. A., \& Ramos, M. A. (1972). A constituição e a distribuição da fauna de decápodos do litoral este da America do Sul entre as latitudes de $5 \mathrm{~N} \mathrm{e}$ 39 S. Trabalhos Oceanograficos da Universidade Federal do Pernambuco, Recife, 13, 133-236.

Coelho, P. A., \& Ramos, M. A. (1980). Crustáceos decápodos da costa do Maranhão. Boletím do Instituto Oceanográfico, São Paulo, 29, 135-138.

Coutière, H. (1909). The American species of snapping shrimps of the genus Synalpheus. Proceedings of the United States National Museum, 36, 1-93.

Crosnier, A., \& Forest, J. (1966). Crustacés Décapodes: Alpheidae. In Campagnes de la Calypso dans le Golfe de Guinée et aux Iles Principe, São Tomé et Annobon (1956), et Campagne aux Iles du Cap Vert (1959). Part 19: Résultats Scientifiques des Campagnes de la Calypso 7(27). Annales de l'Institut Océanographique de Monaco, 44, 199-314.

Dana, J. D. (1852). Crustacea. Part I. In U.S. Exploring Expedition, during the years 1838, 1840, 1841, 1842, under the command of Charles Wilkes, U.S.N.. pp. 1-685.

Edmondson, C. H. (1946). Reef and shore fauna of Hawaii (Vol. 22) Special Publication, B.P. Bishop Museum.

Fausto-Filho, J. (1974). Stomatopod and decapod crustaceans of the Archipelago of Fernando do Noronha, Arquivos de Ciências do Mar. Arquivos de Ciências do Mar, 14, 1-35.

Flores-Hernández, P. (1991). Taxonomía y distribución geográfica de tres familias de camarones carídeos (Crustacea: Decapoda) intermareales de la islas del Golfo de California, México M. Sc. thesis. Facultad de Ciencias, Universidad Nacional Autónoma de México, México, D.F.

Foster, M. S., McConnico, L. M., Lundsten, L., Wadsworkth, T., Kimball, T. Brooks, L. B., et al. (2007). Diversidad e historia natural de una comunidad de Lithohamnion muelleri y Sargassum horridum en el Golfo de California. Ciencias Marinas, 33, 367-384.

Fransen, C. H. J. M. (2002). Taxonomy, phylogeny, historical biogeography, and historical ecology of the genus Pontonia (Crustacea: Decapoda: Caridea: Palaemonidae). Zoologische Verhandelingen, Leiden, 336, 1-433.

Gotelli, N. J., \& Abele, L. G. (1983). Community patterns of coral-associated decapods. Marine Ecology Progress Series, 13, 131-139.

Hayashi, K. I. (1975). The Indo-West Pacific Processidae (Crustacea, Decapoda, Caridea). Journal of the Shimonoseki University of Fisheries, 24, 47-145.

Hendrickx, M. E. (1990). New geographic distribution and batimetric records of Processidae (Caridea) and Penaeidae (Penaeoidea) in the Gulf of California, Mexico. Investigaciones Marinas CICIMAR, 5, 93-95.

Hendrickx, M. E. (1993a). Crustáceos decápodos del Pacífico Mexicano. In S. I. Salazar-Vallejo, \& N. E. González (Eds.), Biodiversidad marina y costera de México (pp. 271-318). México, D.F.: Comisión Nacional para el Estudio y Uso de la Biodiversidad y CIQRO.

Hendrickx, M. E. (1993b). Crustáceos decápodos bentónicos del sur de Sinaloa, México. Anales del Instituto de Biología, Universidad Nacional Autónoma de México, Serie Zoología, 64, 1-16.

Hendrickx, M. E. (1994). Catálogo de crustáceos estomatópodos y decápodos. Colección de referencia, estación Mazatlán, ICMyL, UNAM. México, D.F.: Conabio/UNAM.

Hendrickx, M. E. (2001). New distribution, size and habitats records of decapod crustaceans from the eastern tropical Pacific. Revista de Biología Tropical, 49, 395-397.

Hendrickx, M. E. (2005). Cap. 14. Crustacea 6. Decapoda: Dendrobranchiata, Caridea, Palinura, Anomura and Brachyura. In M. E. Hendrickx, R. C. Brusca, \& L. T. Findley (Eds.), A distributional checklist of the macrofauna of the Gulf of California, Mexico. Part I. Invertebrate (Listado y distribución de la macrofauna del Golfo de California, México) (pp. 159-194). Arizona: Arizona-Sonora Desert Museum.

Hendrickx, M. E. (2008). New records and notes on decapod crustaceans in the East Pacific. Crustaceana, 81, 999-1006.

Hendrickx, M. E., Demestre, M., Esparza-Haro, A., \& Salgado-Barragán, J. (1997). Stomatopod and decapod crustacean collected during the CEEMEX P5 and CEEMEX P7 cruises to the Gulf of Tehuantepec, Mexico. Oceánides, $11,1-28$.

Hendrickx, M. E., \& Hermoso-Salazar, M. (2005). Distribution and habitat of four species of Alpheus Fabricius, 1798 (Alpheus bellimanus Lockington, 1878; A. cristulifrons Rathbun, 1900; A. panamensis Kingsley, 1878; and
A. malleator Dana, 1852) (Caridea, Alpheidae) along the Pacific coast of Mexico. Crustaceana, 78, 429-435.

Hendrickx, M. E., \& Wicksten, M. K. (1987). Studies of the coastal marine fauna of southern Sinaloa. VIII. Additional report on the caridean crustaceans. Universidad Nacional Autónoma de México, Anales del Instituto de Ciencias de Mar y Limnología, 14, 13-20.

Hendrickx, M. E., \& Wicksten, M. K. (2011). New distribution ranges and records of caridean shrimps (Crustacea: Decapoda: Caridea) from the west coast of Mexico. Hidrobiológica, 21, 26-33.

Hendrickx, M. E., Wicksten, M. K., \& van der Heiden, A. M. (1983). Studies of the coastal marine fauna of southern Sinaloa, Mexico. IV. Report on the caridean crustaceans. Proceedings of the Biological Society of Washington, 96, 67-78.

Hermoso-Salazar, A. M. (1999). Camarones carideos (Crustacea: Decapoda) intermareales del Pacífico Tropical Mexicano: de Isla María Madre a las bahías de Huatulco M. Sc. Thesis. Universidad Nacional Autónoma de México, México, D.F.

Hermoso-Salazar, A. M. (2009). Sistemática y biogeografía del género Synalpheus (Decapoda: Caridea) del Pacífico Oriental Ph. D. Thesis. Universidad Nacional Autónoma de México, México, D.F.

Hermoso-Salazar, A. M., \& Álvarez, F. (2005). Synalpheus lani, a new species from the Mexican Pacific (Crustacea: Caridea: Alpheidae). Proceedings of the Biological Society of Washington, 118, 522-527.

Hermoso-Salazar, M., \& Hendrickx, M. E. (2005). New records for Synalpheus peruvianus Rathbun, 1910 (Decapoda, Caridea, Alpheidae) in the east Pacific. Crustaceana, 78, 763-765.

Hermoso-Salazar, M., \& Hendrickx, M. E. (2006). Two new species of Synalpheus Bate, 1888 (Decapoda, Caridea, Alpheidae) from the SE Gulf of California, Mexico. Crustaceana, 78, 1099-1116.

Hermoso-Salazar, A. M., \& Hernández-Alcántara, P. (2001). Range extension of caridean shrimps (Crustacea: Decapoda) from Caleta de Campos, Mexican Pacific. Revista de Biología Tropical, 49, 1279-1280.

Hermoso-Salazar, A. M., \& Suárez-González, I. (2001). Ampliación de ámbito de Synalpheus bannerorum (Decapoda: Caridea) en el Golfo de California. Revista de Biología Tropical, 49, 1278.

Hermoso-Salazar, M., Wicksten, M., \& Morrone, J. J. (2005). Redescriptions and taxonomic notes on species of the Synalpheus townsendi Coutière, 1909 complex (Decapoda: Caridea: Alpheidae). Zootaxa, 1027, 1-26.

Hernández, L., Balart, E. F., \& Reyes-Bonilla, H. (2008). Effect of hurricane John (2006) on the invertebrates associated with corals in Bahía de la Paz, Gulf of California. In Proceedings 11th International Coral Reef Symposium.

Hernández, L., Balart, E. F., \& Reyes-Bonilla., H. (2009). Checklist of reef decapod crustaceans (Crustacea: Decapoda) in the southern Gulf of California. Zootaxa, 2119, 39-50.

Hernández, L., Reyes-Bonilla, H., \& Balart, E. F. (2010). Efecto del blanqueamiento del coral por baja temperatura en los crustáceos decápodos asociados a arrecifes del suroeste del Golfo de California. Revista Mexicana de Biodiversidad, 81, S113-S119.

Hernández, L., Ramírez-Ortiz, G., \& Reyes-Bonilla, H. (2013). Coral-associated decapods (Crustacea) from the Mexican Tropical Pacific coast. Zootaxa, 3609, 451-464.

Hernández-Aguilera, J. L., \& Martínez-Guzmán, L. A. (1992). Notas acerca de la distribución de los estomatópodos y decápodos de aguas someras de la isla Clarión, archipiélago Revillagigedo, Colima, México. Proceeding of the San Diego Society of Natural History, 19, 1-6.

Holguín-Quiñones, O. E., Félix-Pico, E. F., \& Villareal-Chávez, G. (2002). Crustáceos de franja litoral y fondos someros del Parque Marino Nacional Bahía de Loreto, BCS. In M. E. Hendrickx (Ed.), Contribuciones al estudio de los crustáceos del Pacífico este (Vol. 1) (pp. 157-181). Mazatlán: Instituto de Ciencias del Mar y Limnología, UNAM.

Holthuis, L. B. (1951). A general revision of the Palaemonidae (Crustacea Decapoda Natantia) of the Americas. I. The subfamilies Euryrhynchinae and Pontoniinae. Allan Hancock Foundation Publications, Occasional Papers, 11, 1-332.

Holthuis, L. B. (1952). A general revision of the Palaemonidae (Crustacea Decapoda Natantia) of the Americas. II. The subfamily Palaemoninae. Allan Hancock Foundation Publications, Occasional Paper, 12, 1-400. 
Kim, W., \& Abele, L. G. (1988). The snapping shrimp genus Alpheus from the eastern Pacific (Decapoda: Caridea: Alpheidae). Smithsonian Contributions to Zoology, 454, 1-119.

Lockington, W. N. (1878). Remarks on some new Alphei, with a Synopsis of the North American Species. The Annals and Magazine of Natural History, Series, 51, 465-480.

López-Uriarte, E., \& Ríos-Jara, E. (2004). Guía de macrofauna marina asociada a comunidades de coral del Pacífico central Mexicano: corales pétreos y crustáceos. Guadalajara: Centro Universitario de Ciencias Biológicas y Agropecuarias, Universidad de Guadalajara.

Luke, S. R. (1977). Catalog of the benthic invertebrate collections I. Decapod Crustacea and Stomatopoda. Scripps Institution of Oceanography, 77, 1-72.

Macdonald, K. S., Ríos, R., \& Duffy, J. E. (2006). Biodiversity, host specificity, and dominance by eusocial species among sponge dwelling alpheid shrimp on the Belize Barrier Reef. Diversity and Distributions, 12, 165-178.

Martínez-Guerrero, B. (2007). Nuevos registros de camarones carideos intermareales (Crustacea: Caridea) de la costa de Oaxaca, México. In M. E. Hendrickx (Ed.), Contributions to the study of East Pacific Crustaceans 4(2) (Contribuciones al Estudio de los Crustáceos del Pacífico Este 4(2)) (pp. 47-53). Mazatlán: Instituto de Ciencias del Mar y Limnología, UNAM.

Martínez-Guerrero, B., \& Hendrickx, M. E. (2011). Four new records of caridean shrimps (Decapoda: Palaemonidae, Alpheidae) in Mexican Pacific waters. Crustaceana, 84, 1111-1115.

Martínez-Iglesias, J. C., Carvacho, A., \& Ríos, R. (1996). Catálogo de los carídeos marinos (Crustacea, Decapoda, Caridea) de las aguas someras de Cuba. Avicennia, 4/5, 27-40.

Martínez-Iglesias, J. C., Gómez, O., Carvacho, A., \& Ríos, R. (1993). Nuevos registros de crustáceos decápodos (Crustacea: Decapoda) en la plataforma marina de Cuba. Avicennia, 9-13.

McClure, M. (2005). Alpheidae. In J. L. Hernández-Aguilera, J. A. Ruiz-Nuño, R. E. Toral-Almazán, \& V. Arenas-Fuentes (Eds.), Camarones, langostas y cangrejos de la costa este de México (Vol. 1) (pp. 119-202). México, D.F.: Estudio y Conservación de la Naturaleza, A.C. - Conabio.

McClure, M. R., \& Wicksten, M. K. (2000). Taxonomic studies of snapping shrimp of the Alpheus "edwardsii" group from the Galapagos Islands (Decapoda: Caridea: Alpheidae). Proceedings of the Biological Society of Washington, 113, 964-973.

Miranda, A., Ambriz, G., Valencia, D., Sánchez, M., \& Szekely, A. (2011). Programa de manejo del santuario de las islas de la bahía de Chamela: islas La Pajarera, Cocinas, Mamut, Colorada, San Pedro, San Agustín, San Ándres y Negrita, e islotes Los Anegados, Novillas, Mosca y Submarino, Jalisco, México. México, D.F.: Comisión Nacional de Áreas Naturales Protegidas.

Murtaugh, M. P., \& Hernández, L. (2014). Checklist of the macro-fauna recruited onto suspended artificial substrate in Bahía Concepción, Baja California Sur, Mexico. Revista Mexicana de Biodiversidad, 85, 42-413.

Pequegnat, L. H., \& Ray, J. P. (1974). Crustacea and other arthropods. In T. J. Bright, \& L. H. Pequegnat (Eds.), Biota of the West Flower Garden Bank (pp. 232-261). Houston: Gulf Publishers.

Pereyra, R. T., \& Sánchez, C. A. (2000). New geographical records of nine species of crustaceans from southern Baja California, Mexico. Bulletin Southern California Academy of Sciences, 99, 171-173.

Ramos, G. E. (1995). Neopontonides henryvonprahli, una nueva especie de camarón pontoníno del Pacífico de Colombia (Decapoda: Palaemonidae) simbionte de las gorgonias Muricea robusta y Lophogorgia alba. Revista de Biología Tropical, 43, 231-237.

Ramos, G. E., \& Von Prahl, H. (1989). Alpheus utriensis, new species (Caridea: Alpheidae) from Utria Sound, Pacific coast of Colombia. Journal of Crustacean Biology, 9, 477-481.

Randall, J. E., Lobel, P. S., \& Kennedy, C. W. (2005). Comparative ecology of the gobies Nes longus and Ctenogobius saepepallens, both symbiotic with the snapping shrimp Alpheus floridanus. Environmental Biology of Fishes, 74, 119-127.

Rathbun, M. J. (1900). The decapod and stomatopod Crustacea, Part I. In Results of the Branner-Agassiz Expedition to Brazil. Proceedings of the Washington Academy of Sciences, 2, 133-156.

Rathbun, M. J. (1910). The stalk-eyed Crustacea of Peru and the adjacent coast. Proceedings of the United States National Museum, 38, 531-620.
Ray, J. P. (1974). A study of the coral reef crustaceans (Decapoda and Stomatopoda) of two Gulf of Mexico reef systems: West Flower Garden, Texas and Isla de Lobos, Veracruz, Mexico Ph. D. Thesis. College Station: Texas A\&M University.

Ríos, R. (1989). Un catálogo de camarones carideos de Mulegé y Bahía Concepción, B.C.S., con anotaciones acerca de su biología, ecología, distribución geográfica y taxonomía, Thesis. Universidad Autónoma de Baja California Sur, La Paz, B.C.S.

Ríos, R. (1992). Camarones carideos del golfo de California. VI. Alpheidae del estuario de Mulegé y de Bahía Concepción, Baja California Sur, México (Crustacea: Caridea). Proceedings of the San Diego Society of Natural History, 14, 1-13.

Ríos, R., \& Carvacho, R. (1982). Caridean shrimps of the Gulf of California. I. New records, with some remarks on amphiamerican distribution. Pacific Science, 36, 459-465.

Rodríguez, G. (1980). Crustáceos decápodos de Venezuela. Caracas: Instituto Venezolano de Investigaciones Científicas.

Rodríguez, B. (1986). Los camarones (Crustacea; Decapoda; Natantia) del Parque Nacional Archipiélago de los Roques Thesis. Universidad Central de Venezuela: Caracas, Venezuela.

Rodríguez-Almaraz, G. A., Gallardo-Tejeda, W., \& Campos, E. (2002). Crustáceos decápodos intermareales de la Isla Carmen, Baja California Sur, México, con notas sobre su distribución ecológica. In M. E. Hendrickx (Ed.), Contributions to the Study of East PacificCrustaceans (pp. 255-264). México, D.F: Instituto de Ciencias del Mar y Limnología, UNAM.

Rodríguez-Almaraz, G. A., Leija-Tristán, A., \& Mendoza, R. (2000). Records of caridean shrimps (Crustacea: Decapoda) from the coast of the Mexican Pacific Ocean, Gulf of Mexico and Mexican Caribbean. Bulletin of Marine Science, 67, 857-867.

Rodríguez-de la Cruz, R. M. C. (1977). Decápodos marinos del Golfo de California, M. Sc. Thesis. Escuela de Ciencias Marítimas y Alimentarias del I.T.Y.E.S.M., Guaymas, Sonora.

Rodríguez-de la Cruz, M. C. (1987). Crustáceos decápodos del Golfo de California. México, D.F: Secretaría de Pesca.

Román, R. (1979). Contribución al conocimiento de la biología y ecología de Macrobrachium tenellum (Smith) (Crustacea, Decapoda, Palaemonidae) Anales del Centro de Ciencias del Mar y Limnología, 6, 137-160.

Román, R. (2004). The genus Probopyrus Giard and Bonnier, 1888 (Crustacea: Isopoda: Bopyridae) in the eastern Pacific with seven new records for Mexico. In M. E. Hendrickx (Ed.), Contributions to the study of East Pacific Crustaceans 3 (pp. 153-168). México, D.F.: Instituto de Ciencias del Mar y Limnología, UNAM.

Salazar-Rosas, A. G. (1995). Taxonomía y distribución geográfica de los camarones carídeos de la familia Alpheidae (Crustacea: Decapoda: Caridea) de aguas someras del litoral de Quintana Roo, México M. Sc. Thesis. Facultad de Ciencias, Universidad Nacional Autónoma de México, México, D.F

Salgado-Barragán, J., Ayón-Parente, M., \& Hendrickx, M. E. (2014). A new species of Leptalpheus Williams, 1965 and new records of L. mexicanus Ríos and Carvacho, 1983 and L. hendrickxi Anker, 2011 (Crustacea: Decapoda: Alpheidae) from the Pacific coast of Mexico. Zootaxa, 3835, 573-582.

Schmitt, W. L. (1939). Decapod and other Crustacea collected on the Presidential Cruise of 1938 (with introduction and station data). Smithsonian Miscellaneous Collections, 98, 1-29.

Silliman, B. R., Layman, C. A., \& Altieri, A. H. (2003). Symbiosis between an alpheid shrimp and a xanthoid crab in salt marshes of mid-Atlantic states, USA. Journal of Crustacean Biology, 23, 876-879.

Sivertsen, E. (1933). The Norwegian zoological expedition to the Galapagos Islands 1925, conducted by Alf Wollebaek. VII. Littoral Crustacea Decapoda from the Galapagos Islands. Meddelelser fre det Zoologiske Museum, 38 , $1-23$.

Steinbeck, J., \& Ricketts, E. F. (1941). Sea of Cortez. A leisurely journal of travel and research. New York: Viking Press.

Sterrer, W. (1986). Marine fauna and flora of Bermuda. A systematic guide to the identification of marine organisms. New York: John Wiley \& Sons.

van der Heiden, A. M., \& Hendrickx, M. E. (1979). Inventario de la fauna marina y costera del sur de Sinaloa, México (list of the marine and coastal 
fauna of southern Sinaloa, México). Mazatlán, Sinaloa: Estación Mazatlán, UNAM.

Vargas, R., \& Cortés, J. (1999). Biodiversidad marina de Costa Rica: Crustacea: Decapoda (Penaeoidea, Sergestoidea, Stenopodidea, Caridea, Thalassinidea, Palinura) del Caribe. Revista de Biología Tropical, 47, 887-911.

Villalobos-Hiriart, J. L. (2000). Estudio monográfico de los crustáceos decápodos no braquiuros de la zona intermareal de las islas del Golfo de California, México (M.Sc. thesis). México, D.F.: Facultad de Ciencias, Universidad Nacional Autónoma de México.

Villalobos-Hiriart, J. L., Nates-Rodríguez, J. C., Cantu-Díaz-Barriga, A., ValleMartínez, M. D., Flores-Hernández, P., Lira-Fernández, E., et al. (1989). Listados faunísticos de México. I. Crustáceos estomatópodos y decápodos intermareales de las islas del Golfo de California. México. México, D.F.: Instituto de Biología, Universidad Nacional Autónoma de México.

Wicksten, M. K. (1983). A monograph on the shallow-water Caridean shrimps of the Gulf of California, Mexico. Allan Hancock Foundation Monographs, $13,1-59$.

Wicksten, M. K. (1987). A new species of hippolytid shrimp from the west coast of Mexico. Bulletin of the Southern California Academy of Sciences, $86,27-33$

Wicksten, M. K. (1996). Decapod crustaceans and pycnogonids of Rocas Alijos. In R. W. Schmieder (Ed.), Rocas Alijos (pp. 285-293). Dordrecht, The Netherlands: Kluwer Academic Publishers.

Wicksten, M. K. (2000). The species of Lysmata (Caridea: Hippolytidae) from the Eastern Ocean Pacific. Amphipacifica, 2, 3-22.
Wicksten, M. K., \& Hendrickx, M. E. (1985). New records of caridean shrimps in the Gulf of California, Mexico. Proceedings of the Biological Society of Washington, 98, 571-573.

Wicksten, M. K., \& Hendrickx, M. E. (1992). Checklist of penaeoid and caridean shrimps (Decapoda: Penaeoidea, Caridea) from the eastern tropical Pacific. Proceedings of the San Diego Society of Natural History, 9, $1-11$.

Wicksten, M. K., \& Hendrickx, M. E. (2003). An updated checklist of benthic marine and brackish water shrimps (Decapoda: Penaeoidea, Stenopodidea, Caridea) from the eastern tropical Pacific. In M. E. Hendrickx (Ed.), Contributions to the study of East Pacific Crustaceans (Vol. 2) (pp. 49-76). Mazatlán: Instituto de Ciencias del Mar y Limnología, UNAM.

Wicksten, M. K., \& Hernández, L. (2000). Range extensions, taxonomic notes and zoogeography of symbiotic caridean shrimp of the Tropical Eastern Pacific (Crustacea: Decapoda: Caridea). Bulletin of the Southern California Academy of Sciences, 99, 91-100.

Wicksten, M. K., \& Méndez, M. (1983). Nuevos registros de camarones carideos en el Perú. Boletín de Lima, 25, 75-89.

Wicksten, M. K., \& Vargas, R. (2001). A new species of Thor Kingsley, 1878 (Crustacea: Decapoda: Caridea: Hippolytidae) from the tropical eastern Pacific. Proceedings of the Biological Society of Washington, 114, 139-144.

Williams, S. T., Knowlton, N., Weigt, L. A., \& Jara, J. A. (2001). Evidence for three major clades within the snapping shrimp genus Alpheus inferred from nuclear and mitochondrial gene sequence data. Molecular Phylogenetics and Evolution, 20, 375-389. 